\title{
Seaweeds from the Portuguese coast as a source of proteinaceous material: Total and free amino acid composition profile
}

\author{
Elsa Ferreira Vieira , Cristina Soares, Susana Machado , Manuela Correia , Maria João Ramalhosa, Maria \\ Teresa Oliva-teles , Ana Paula Carvalho , Valentina Fernandes Domingues , Filipa Antunes , Teresa \\ Azevedo Cardoso Oliveira , Simone Morais, Cristina Delerue-Matos
}

\begin{abstract}
The total protein content and the (total and free) amino acid composition of nine edible species of red, brown and green seaweeds collected in the Portuguese North-Central coast were quantified to assess their potential contribution to the recommended dietary intake. Whenever possible, the protein and amino acid composition was compared with that of commercial European seaweeds. The protein content was the highest $(P<0.05)$ in red species (19.1-28.2 g/100g dw), followed by the green seaweed Ulva spp. (20.5-23.3g/100g dw), with the lowest content found in brown seaweeds (6.90-19.5g/100 g dw). Brown seaweeds presented the lowest mean contents of essential amino acids (EAAs) (41.0\% protein) but significantly $(P<0.05)$ higher concentrations of non-essential amino acids (36.1\% protein) and free amino acids $(6.47-24.0 \%$ protein). Tryptophan, methionine and leucine were the limiting EAAs in all species. In contrast, lysine was found in high concentrations, especially in red (2.71-3.85\% protein) and green (2.84-4.24\% protein) seaweeds.
\end{abstract}

Keywords

Seaweeds; North-Central coast of Portugal; Protein quality; Total and free amino acids; RP-HPLC 


\section{Introduction}

Seaweeds have been traditionally used as a food source in many Asian countries, with a contribution ranging from $10 \%$ to $25 \%$ of food intake (Mišurcová et al., 2014). In Europe, although seaweeds have received great attention for human food in the last decades, they have been mostly exploited for a variety of biotechnological purposes, including cosmeceuticals, animal feed, fatty acids and alginates production, wastewater treatment, and as biofuel (Makkar et al., 2016, Bleakley and Hayes, 2017). Norway, France and Ireland are the dominant seaweed suppliers, whereas Spain, Portugal and the United Kingdom are small producers and suppliers (Peinado, Girón, Koutsidis, \& Ames, 2014).

Seaweeds are macroscopic marine algae, taxonomically classified as red (Rhodophyta), brown (Phaeophyta) or green (Chlorophyta), depending on the nature of their pigments (Peinado et al., 2014, Mišurcová et al., 2014, Bleakley and Hayes, 2017). In general, seaweeds are recognized for their richness in minerals and certain vitamins, as well as the presence of bioactive substances such as polysaccharides, proteins, lipids and polyphenols claimed to have a medicine-like effect in treating or preventing certain diseases (Déléris et al., 2016, Rioux et al., 2017). The nutritional composition of seaweeds depends on the developmental stage and mostly on environmental factors, namely, geographical location, habitat, season and nutrient content of the growth medium (Holdt and Kraan, 2011, Peinado et al., 2014).

The protein content presents high variability, ranging from 10 to $30 \%$ of dry weight ( $\mathrm{dw}$ ) in red seaweeds, 5 to $15 \% \mathrm{dw}$ in brown seaweeds and 3 to $47 \%$ dw in green seaweeds (Kadam et al., 2017, Rodrigues et al., 2015). According to literature, the highest protein contents in seaweeds are found during the period of winter-early spring and the lowest during summer-early autumn (Pangestuti \& Kim, 2015). The essential amino acids (EAAs) composition represents almost half of total amino acids (Černá, 2011) and meets the Food and Agriculture Organization of the United Nations requirements for EAAs (FAO, 1991) with levels comparable to those found in traditional high-protein sources such as meat, egg, soybean and milk (Bleakley \& Hayes, 2017). This gives seaweeds great potential to be exploited as a source of proteins and as supplement in functional food or for the extraction of valuable compounds (Holdt \& Kraan, 2011). Nevertheless, seaweed protein digestibility appears to be limited by the presence of various anti-nutritional compounds, such as polysaccharides (xylans, agar, carrageenan, or alginates), lectins, protease inhibitors, goitrogens, allergens, anti-vitamins, saponins, tannins and phytate (Silva et al., 2015, Fleurence et al., 2018, Mišurcová et al., 2010). The presence of toxic compounds, such as heavy metals or fucotoxins - if present in its natural environment - can also be a limiting factor for their use in food industry (Mišurcová et al., 2010).

Portugal presents one of the largest exploration marine areas in Europe, with a very rich and diverse seaweed flora (Mare, 2014). To date, whilst scientific research has been carried out on the nutritional composition of potentially edible seaweeds of this region, such as Osmundea pinnatifida, Saccorhiza polyschides, Fucus spiralis, and Porphyra sp. (Paiva et al., 2014, Patarra et al., 2013, Rodrigues et al., 2015), scarce information exists concerning the amino acid content, particularly, the free fraction recognized for its role in the taste sensation referred to as 'umami' (Yamaguchi, \& Ninomiya, 2000). Moreover, most of the previous studies of the amino acid content of seaweeds have considered species obtained from aquaculture and do not take in account the seasonal variations of the protein material.

This study aimed to characterize nine different edible seaweeds (four species of red seaweeds, four species of brown seaweeds and one species of green seaweed) collected on the North-Central coast of Portugal in terms of (i) protein content, (ii) total and free amino acid profile, (iii) amino acid score and their contributions to recommended daily intakes (RDIs) of EAAs, and (iv) seasonal variations of the protein material. In addition, the amino acid profiles of wild seaweeds collected in the North-Central coast of Portugal were compared with those of ten commercial European seaweeds available in the Portuguese market (wild and from aquaculture).

\section{Material and methods}

\subsection{Chemicals and reagents}

HPLC-grade acetonitrile and methanol, tetrahydrofuran (THF), orthoboric acid, methanesulfonic acid (MSA); o-phthalaldehyde (OPA); 9fluorenylmethyl chloroformate (FMOC) and tryptamine [3-(2-aminoethyl)indole] were purchased from Sigma-Aldrich (Steinheim, Germany). Ultrapure water used for the preparation of all reagents, eluents, and buffers was obtained from a Milli-Q-simplicity 185 system (Millipore, Bedford, MA, USA). All solutions and reagents were filtered through $0.2 \mu \mathrm{m} \mathrm{MS}^{\circledR}$ Nylon membrane filters. The amino acid standards alanine (Ala), aspartic acid (Asp), arginine (Arg), asparagine (Asn), glutamic acid (Glu), glycine (Gly), hydroxyproline (Hyp); histidine (His), isoleucine (Ile), leucine (Leu), lysine (Lys), methionine (Met), norvaline (Nva), phenylalanine (Phe), proline (Pro), serine (Ser), taurine (Tau), tyrosine (Tyr), threonine (Thr) and valine (Val) were from Sigma-Aldrich (Steinheim, Germany); the amino acid standards glutamine (Gln) and tryptophan (Trp) were purchased from Merck (Darmstadt, Germany).

\subsection{Seaweeds sampling}

Fifty four samples of seaweeds were collected between April and July 2016 (batch A) and between October and November 2016 (batch B), including four species of red seaweeds: Chondrus crispus (C. crispus), Gracilaria sp., Osmundea pinnatifida (O. pinnatifida) and Porphyra spp.; four different species of brown seaweeds: Ascophyllum nodosum (A. nodosum), Fucus spiralis (F. spiralis), Saccorhiza polyschides (S. polyschides) and Undaria pinnatifida (U.pinnatifida); and one species of green seaweed (Ulva spp.; no other green species was available). The sampling sites in the North-Central coast of Portugal included Praia Norte in Viana do Castelo, Aguda in Vila Nova de Gaia and Buarcos in Figueira da Foz (Fig. 1). Seaweed material was collected manually cutting the fronds, washed with seawater and stored in opaque plastic bags with excess water during transportation to the laboratory. Seaweed samples were identified based on examination of morphological characteristics and comparison to the MACOI Portuguese Seaweeds website database (Pereira, 2012). Ten European dried seaweeds (Table 1), commercially available in Portugal, were purchased in local health products stores. 


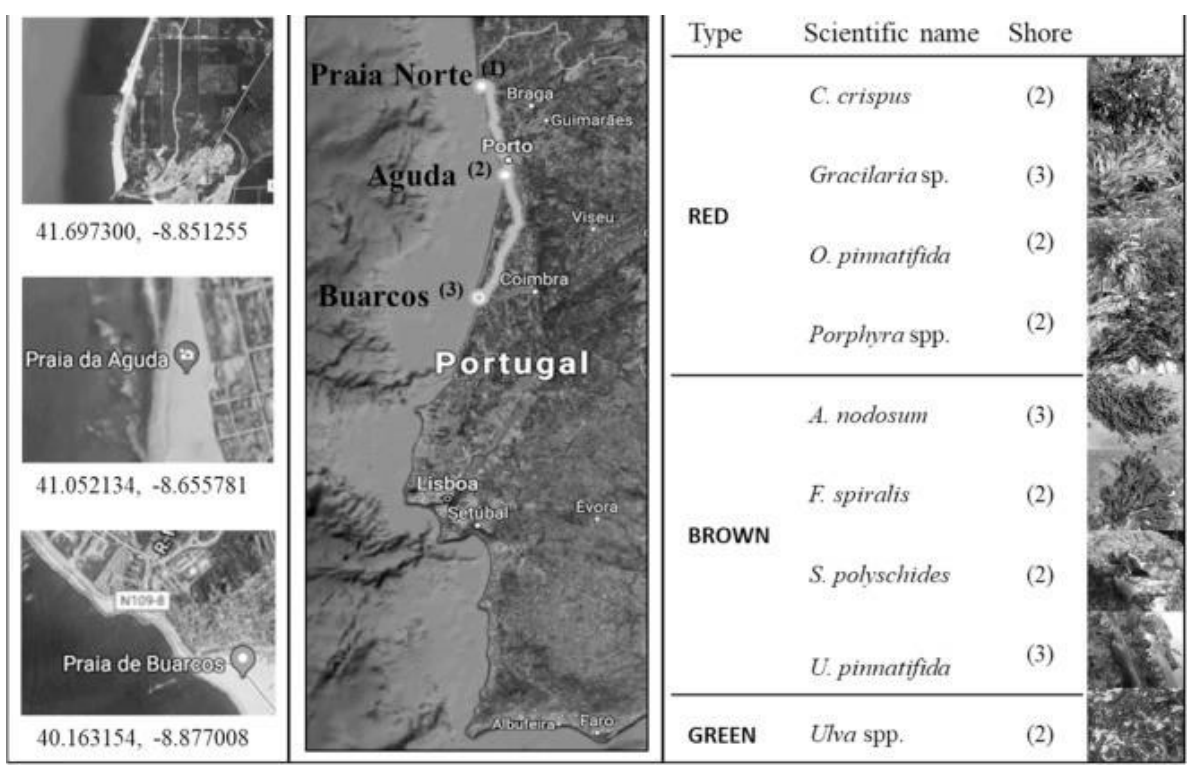

Fig. 1. Location and GPS coordinates of the shores considered for seaweeds harvesting in the North-Central coast of Portugal: Praia Norte in Viana do Castelo, Aguda in Vila Nova de Gaia and Buarcos in Figueira da Foz.

Table 1. Label information of commercial European dried seaweeds.

\begin{tabular}{|c|c|c|c|c|c|}
\hline Seaweed species & Type & Origin & Country of origin & Protein content $(\mathrm{g} / 100 \mathrm{~g})$ & Recommended dose on product label (g per day) \\
\hline C. crispus & red & aquaculture & Portugal & 15.7 & 30 \\
\hline C. crispus & red & wild & France & 16.6 & Not specified \\
\hline Porphyra spp. & red & aquaculture & Portugal & 27.6 & 30 \\
\hline P. palmata & red & aquaculture & Portugal & 17.2 & 30 \\
\hline A. nodosum & brown & wild & France & 7.2 & Not specified \\
\hline F. vesiculosus & brown & wild & France & 7.4 & Not specified \\
\hline H. elongata & brown & wild & Spain & 8.4 & Not specified \\
\hline Laminaria sp. & brown & wild & Spain & 6.9 & Not specified \\
\hline U. pinnatifida & brown & wild & Spain & 12.6 & 5 \\
\hline Ulva spp. & green & aquaculture & Portugal & 16.3 & 30 \\
\hline
\end{tabular}

\subsection{Sample preparation}

Within half a day from collection, samples were first washed with $35 \mathrm{~g} / \mathrm{L} \mathrm{NaCl}$ solution to remove seawater and foreign matter, then carefully rinsed with deionized water and partially dried with a paper towel. The material was then dried at $52^{\circ} \mathrm{C}$ (Excalibur 9 Tray Dehydrator, Model 4926 T, USA) for 6-8 h, packed in polypropylene bags and kept in the dark at room temperature until usage. Before performing the analyses, samples were milled in a mechanical grinder (Moulinex A320) for 5 min to obtain a fine and homogeneous powder.

\subsection{Moisture determination}

The moisture of fresh and commercial seaweeds samples was estimated using a moisture balance, KERN MLS50 160-3 Infra Red analyser. The moisture values were in the range of $66 \%$ (C. crispus) to $95 \%$ (O. pinnatifida) for red seaweeds; between $62 \%$ ( $A$. nodosum) and $95 \%$ ( 5 . polyschides) for brown seaweeds; and $86 \%$ to $94 \%$ for Ulva spp. The average moisture content of the dried commercial seaweed samples was $7-$ $9 \%$.

\subsection{Determination of crude protein content}

The organic nitrogen content was quantified using the modified Kjeldahl procedure (AoAC, 2000). Samples were digested in a DK6 Heating digester (Velp Scientific, Usmate, Italy) and distilled in a Keltec System 1002 Distilling Unit (Foss Tecator, Hilleroed Denmark). Estimation of the crude protein content was calculated multiplying the organic nitrogen by a conversion factor of 6.25 (Peinado et al., 2014 , Rodrigues et al., 2015, Astorga-España et al., 2016); the protein content was expressed as g/100g dw. All samples were analysed in duplicate. 


\subsubsection{Sample hydrolysis}

\subsubsection{Total fraction}

Hydrolysis of total protein was performed according to the protocol described by Malmer and Schroeder (1990). Briefly, $20 \mathrm{mg}$ of sample were placed in $16 \mathrm{~mm} \times 25 \mathrm{~mm}$ screw-cap tubes and $2 \mathrm{~mL}$ of MSA $4 \mathrm{M}$ containing $0.2 \%$ tryptamine (to protect the tryptophan content during acid hydrolysis) were added. The tubes were closed under nitrogen, placed in an electric oven at $110^{\circ} \mathrm{C}$ for $24 \mathrm{~h}$, cooled, and their contents were vacuum-filtered through Whatman no. 4 paper. The filtrate was diluted to $4 \mathrm{~mL}$ with ultrapure water in a glass vial and $1 \mathrm{~mL}$ of the resulting liquid was membrane-filtered (Millipore ${ }^{\circledast} 0.45 \mu \mathrm{m}$ regenerated cellulose membranes) and analysed for total amino acid content using reverse phase high-performance liquid chromatography (RP-HPLC) with fluorescence detection. Each sample was hydrolysed in duplicate.

\subsubsection{Free fraction}

Each sample $(20 \mathrm{mg})$ was placed in $5 \mathrm{~mL}$ eppendorf tubes and perchloric acid $(0.2 \mathrm{M}, 2 \mathrm{~mL})$ was added; the tubes were closed and placed in an ultrasound bath at room temperature for $30 \mathrm{~min}$. The eppendorfs were centrifuged (Sigma ${ }^{\circledR} 2-16 \mathrm{PK}, \mathrm{USA}$ ) at $5000 \mathrm{rpm}$ during $5 \mathrm{~min}$ and the supernatant was collected. The residue was extracted a second time with another $2 \mathrm{~mL}$ of perchloric acid $0.2 \mathrm{M}$, mixed thoroughly in a vortex $\left(V W R^{\circledast}\right.$ mini vortex mixer, USA) and placed in the ultrasound bath during $10 \mathrm{~min}$. After centrifugation the first and second supernatants (extracts) were mixed. The extracts were diluted to $5 \mathrm{~mL}$ with ultrapure water and membrane-filtered (DISMIC $25,0.45 \mu \mathrm{m}, \mathrm{Specanalitica}{ }^{\circledR}$, Portugal) for analysis of free amino acid content using RP-HPLC with fluorescence detection. Each sample was prepared in duplicate.

\subsubsection{RP-HPLC analysis}

Amino acid content was determined by RP-HPLC using a Shimadzu LC system (Shimadzu Corporation, Kyoto, Japan) equipped with an LC20AD pump, DGU-20AS degasser and photodiode array SPD-M20A (PAD) and fluorescence RF-10AXL (FLD) detectors on line. The mobile phase was a mixture of $10 \mathrm{mM}$ phosphate buffer, $\mathrm{pH} 7.2$, containing $0.8 \%$ tetrahydrofuran $(\mathrm{A})$ and 20:50:30 (v/v/v) eluent A-acetonitrilemethanol (B), at a flow rate of $1.2 \mathrm{~mL} \mathrm{~min}^{-1}$. The elution gradient ( $\mathrm{min}, \mathrm{A} \%$ ) was: 0,100; 24,30; 27,0;32,0; 35,100 and 40,100. Samples (total and free amino acid extracts) were derivatized with OPA and FMOC, according to the protocol described by Heems, Luck Fraudeau and Verette (1998). The derivatized amino acid solutions were filtered through a $0.22 \mu \mathrm{m}$ microfiltration membrane and the filtrates (20.0 $\mu \mathrm{L})$ were injected onto the RP-HPLC system equipped with a HPLC column (Luna ${ }^{\circledR} 5 \mu \mathrm{m}$ C18(2) $100 \AA$, $150 \times 4.6 \mathrm{~mm}$, Phenomenex, USA), which was maintained at $40 \pm 0.1{ }^{\circ} \mathrm{C}$ (CTO-20A Prominence HPLC). OPA-3-MPA derivatives were detected by the programmable fluorimeter with excitation $\left(\lambda_{\text {ex }}\right)$ and emission $\left(\lambda_{\text {em }}\right)$ wavelengths set at optimum values i.e. 335 and $440 \mathrm{~nm}$ respectively; the FMOC derivatives were detected at $\lambda_{\mathrm{ex}} 260 \mathrm{~nm}$ and $\lambda_{\mathrm{em}} 315 \mathrm{~nm}$; the wavelength change occurred at $18.5 \mathrm{~min}$. Norvalin was used as internal standard. Amino acid standards were dissolved in $0.1 \mathrm{M}$ hydrochloric acid and diluted as appropriate to obtain the working solutions. Amino acid concentrations in samples were calculated from calibration plots obtained by analysis of working solutions of different concentration; the contents were expressed as $\mathrm{g} / 100 \mathrm{~g}$ of protein. All samples were analysed at least twice.

\subsubsection{Quality control}

The RP-HPLC separation of the derivatized amino acids provided an efficient separation of 21 amino acids in 35 min with wide working ranges and good linearity (Table 1S, Supplementary material). Precision measured in terms of repeatability and reproducibility (\% RSD, $\mathrm{n}=8$ ) was below $8 \%$ for all the analyzed amino acids. Limits of detection (LODs) and limits of quantification (LOQs) were in the range of 0.1-

$1.2 \mu \mathrm{g} / \mathrm{mL}$ and $0.1-4.0 \mu \mathrm{g} / \mathrm{mL}$, respectively. The accuracy was evaluated by the determination of the recovery. This parameter was calculated based on the difference between the total concentration determined in the spiked samples at two concentration levels $(1 \mathrm{and} 2 \mu \mathrm{g} / \mathrm{mL}$, each one executed five times) and the concentration observed in the non-spiked samples. The results were in the range of $78.3-103 \%$ and $74.8-$ $102 \%$ for total and free amino acids, respectively. His (78.3-78.9\%), Pro (80.2-85.2\%), Asn (84.2-85.6\%), Ser (85.2-88.5\%) and Thr (74.8-89.5\%) showed the lowest values of recovery.

\subsection{Nutritional value of seaweed proteins}

Amino acid chemical score (AAS) and Essential amino acid index (EAAI) were used to measure the biological quality of the seaweed proteins. These parameters were calculated according to Friedman (1996) using the FAO/WHO/,UNU (2007) amino acid requirement pattern. The EAAI compares the protein quality by means of the geometric mean value of EAA relative to a reference protein (Dawczynski, Schubert, \& Jahreis, 2007). From AAS, the limiting amino acid was determined as the EAA in seaweed proteins that showed the greatest difference in concentration from the same amino acid in a standard protein.

\subsection{Evaluation of seaweeds EAAs contribution to RDI}

The EAAs contribution of fresh and commercial seaweeds to RDls was calculated using the RDIs for adults with body weight of 70 kg (FAO/WHO/,UNU, 2007). A serving dose of $1 \mathrm{~g}(\mathrm{dw})$ - equivalent to ca. $4 \mathrm{~g}$ of fresh seaweed - of C. crispus, A. nodosum, and U. pinnatifida; and a serving portion of $5 \mathrm{~g}(\mathrm{dw})$ - equivalent to $c a$. $20 \mathrm{~g}$ of fresh seaweed - of Porphyra spp. and Ulva spp. were used to calculate the EAAs contribution to RDIs. The recommended doses in the label information of the commercial seaweeds samples were, where stated, $30 \mathrm{~g}$ for red and green seaweeds, and $5 \mathrm{~g}$ for brown species (Table 1). Notwithstanding, in this work the serving portion was conveniently adjusted based on the reported iodine levels for the selected seaweed species (Nitschke and Stengel, 2015, Romarís-Hortas et al., 2012) in order not to exceed the safe iodine intake $(600 \mu \mathrm{g} /$ day tolerable upper intake level for adults; Agostoni et al., 2014). Results were expressed as percentages of RDIs for individual EAA, stating the base of seaweed daily intake for each seaweed species. 
Data were expressed as mean \pm standard deviation (SD). Statistical analysis was performed using the software SPSS for Windows, version 20.0 (SPSS Inc., Chicago, IL, USA). The Kolmogorov-Smirnov test was applied to verify whether the distribution of the variables was normal $(P<0.05)$. When the statistical distribution was not normal, the Kruskal-Wallis non-parametric test was applied; when the statistical distribution was normal, one-way ANOVA (Duncan's multiple range) was conducted. Differences were considered significant at $P<0.05$ in both tests. Pearson correlation analysis was carried out to find relationships between variables.

\section{Results and discussion}

\subsection{Protein content}

Table 2 illustrates the protein composition of the nine different species of seaweed harvested in two different times of the year, between April and July 2016 (batch A) and between October and November 2016 (batch B). Results showed significant differences $(P<0.05)$ in the protein composition between the different seaweed species. The mean protein content ranged from $6.90 \mathrm{~g} / 100 \mathrm{~g} \mathrm{dw}(A$. nodosum, batch $\mathrm{A})$ to $28.2 \mathrm{~g} / 100 \mathrm{~g} \mathrm{dw}$ (Porphyra spp., Batch B). Higher values $(P<0.05)$ of protein content were found in the red seaweed species $(19.1-28.2 \mathrm{~g} / 100 \mathrm{~g} \mathrm{dw})$, followed by the characterized green seaweed Ulva spp. $(20.5-23.3 \mathrm{~g} / 100 \mathrm{~g} \mathrm{dw})$ and with the lowest content found in brown seaweed (6.90$19.5 \mathrm{~g} / 100 \mathrm{~g} \mathrm{dw}$ ). These values are in agreement with data published by other authors (Dawczynski et al., 2007, Mišurcová et al., 2010, Holdt and Kraan, 2011, Rodrigues et al., 2015, Astorga-España et al., 2016), who referred that red and green seaweeds are characterized by higher protein content compared to brown seaweed species. Among red seaweed species, C. crispus displayed the lowest values (19.1-19.5 g/100 g dw) and Porphyra spp. presented the highest protein content (27.4-28.2 g/100 g dw). Concerning Porphyra spp., these values are in the same range to those reported by Paiva et al. (2014), 24.8\% dw (sample collection in Azores Archipelago, Portugal) and Astorga-España et al. (2016), 23.0\% dw (sample collection in sub-Antarctic ecoregion of Magallanes, Chile). The mean protein content of O. pinnatifida $(22.8-24.3 \mathrm{~g} / 100 \mathrm{~g} \mathrm{dw})$ was similar to the value described by Rodrigues et al. (2015), $23.8 \mathrm{~g} / 100 \mathrm{~g} \mathrm{dw}$. Among the brown seaweed species, A. nodosum presented the lowest values $(6.90-9.40 \mathrm{~g} / 100 \mathrm{~g} \mathrm{dw})$ and $U$. pinnatifida exhibited the highest values (16.5-19.5 g/100 g dw). These contents were consistent with the respective values of $4.0-12 \mathrm{~g} / 100 \mathrm{~g} \mathrm{dw}$ and $11-24 \mathrm{~g} / 100 \mathrm{~g} \mathrm{dw}$, previously reported in the literature, respectively for those two species (Holdt \& Kraan, 2011). Regarding F. spiralis, similar values were described by Paiva et al. (2014) $(9.71 \mathrm{~g} / 100 \mathrm{~g} \mathrm{dw})$, and the values reported for S. polyschides $(11.80-12.43 \mathrm{~g} / 100 \mathrm{~g} \mathrm{dw})$ were consistent with those presented by Rodrigues et al. (2015), $14.44 \mathrm{~g} / 100 \mathrm{~g} \mathrm{dw}$.

Table 2. Protein content (expressed as $\mathrm{g} / 100 \mathrm{~g} \mathrm{dw}$ ) and concentrations of Total amino acids (expressed as g/100 $\mathrm{g}$ protein) for different types of seaweeds collected in the North-Central coast of Portugal.

\begin{tabular}{|c|c|c|c|c|c|c|c|c|c|c|}
\hline & & Red & & & Brown & & & & & Green \\
\hline \multirow{3}{*}{ Protein $(\mathrm{g} / 100 \mathrm{~g} \mathrm{dw})$} & batch & C. crispus & Gracilariasp. & O. pinnatifida & Porphyra spp. & A. nodosum & F.spiralis & S. polyschides & U. pinnatifida & Ulva spp. \\
\hline & $A$ & $19.5 \pm 0.16$ & $24.7 \pm 0.24$ & $24.3 \pm 0.73$ & $27.4 \pm 0.08$ & $6.90 \pm 0.16$ & $11.8 \pm 0.16$ & $12.4 \pm 0.01$ & $16.5 \pm 0.08$ & $20.5 \pm 0.49$ \\
\hline & B & $19.1 \pm 0.33$ & $24.4 \pm 0.24$ & $22.8 \pm 0.33$ & $28.2 \pm 0.16$ & $9.40 \pm 0.08 *$ & $11.7 \pm 0.24$ & $11.8 \pm 0.16$ & $19.5 \pm 0.21 *$ & $23.3 \pm 0.01 *$ \\
\hline
\end{tabular}

\begin{tabular}{|c|c|c|c|c|c|c|c|c|c|c|}
\hline \multirow[t]{2}{*}{ Asp $^{\#}$} & A & $3.66 \pm 0.19$ & $3.40 \pm 0.23$ & $4.80 \pm 0.36$ & $4.13 \pm 0.26$ & $3.70 \pm 0.01$ & $5.23 \pm 0.14$ & $3.53 \pm 0.07$ & $4.31 \pm 0.01$ & $4.53 \pm 0.29$ \\
\hline & B & $3.56 \pm 0.12$ & $3.14 \pm 0.16$ & $4.94 \pm 0.30$ & $3.93 \pm 0.28$ & $4.13 \pm 0.07$ & $4.87 \pm 0.15$ & $3.79 \pm 0.13$ & $3.98 \pm 0.07$ & $6.10 \pm 0.36^{*}$ \\
\hline \multirow[t]{2}{*}{$\mathrm{Glu}^{\#}$} & A & $3.17 \pm 0.14$ & $3.52 \pm 0.14$ & $4.51 \pm 0.15$ & $4.33 \pm 0.14$ & $6.46 \pm 0.01$ & $7.26 \pm 0.19$ & $4.26 \pm 0.07$ & $7.66 \pm 0.14 *$ & $4.08 \pm 0.18$ \\
\hline & B & $3.58 \pm 0.06$ & $3.21 \pm 0.17$ & $4.30 \pm 0.21$ & $4.33 \pm 0.20$ & $7.23 \pm 0.09$ & $8.12 \pm 0.17^{*}$ & $4.72 \pm 0.07$ & $6.19 \pm 0.14$ & $5.22 \pm 0.27 *$ \\
\hline \multirow[t]{2}{*}{ Ser } & A & $4.67 \pm 0.13$ & $5.06 \pm 0.36$ & $3.95 \pm 0.19$ & $4.67 \pm 0.46$ & $4.54 \pm 0.02$ & $5.53 \pm 0.02$ & $4.64 \pm 0.03^{*}$ & $5.88 \pm 0.14$ & $7.30 \pm 0.05$ \\
\hline & B & $8.30 \pm 0.30 *$ & $7.32 \pm 0.04^{*}$ & $7.14 \pm 0.36^{*}$ & $7.47 \pm 0.47 *$ & $3.90 \pm<0.01$ & $4.56 \pm 0.02$ & $3.92 \pm 0.14$ & $5.77 \pm 0.08$ & $7.86 \pm 0.09$ \\
\hline \multirow[t]{2}{*}{ Thro } & A & $1.43 \pm 0.03$ & $1.11 \pm 0.10$ & $2.73 \pm 0.19^{*}$ & $2.94 \pm 0.02$ & $1.93 \pm 0.01$ & $2.75 \pm 0.12 *$ & $2.12 \pm 0.06$ & $2.40 \pm 0.05$ & $1.73 \pm 0.01$ \\
\hline & B & $2.38 \pm 0.13^{*}$ & $2.14 \pm 0.24$ & $2.21 \pm 0.10$ & $3.17 \pm 0.12$ & $1.94 \pm 0.04$ & $1.83 \pm 0.01$ & $2.37 \pm 0.10$ & $3.35 \pm 0.21^{*}$ & $2.01 \pm 0.01 *$ \\
\hline \multirow[t]{2}{*}{ Hisø } & A & $1.80 \pm 0.02 *$ & $6.20 \pm 0.05$ & $3.69 \pm 0.01 *$ & $1.26 \pm 0.08$ & $1.05 \pm 0.01$ & $1.67 \pm 0.01 *$ & $4.54 \pm 0.20 *$ & $1.47 \pm 0.09 *$ & $3.81 \pm 0.21$ \\
\hline & B & $1.53 \pm 0.01$ & $7.20 \pm 0.18^{*}$ & $1.10 \pm 0.01$ & $1.43 \pm<0.01$ & $1.15 \pm 0.02 *$ & $1.34 \pm 0.01$ & $3.21 \pm 0.02$ & $1.30 \pm 0.04$ & $3.36 \pm 0.01$ \\
\hline \multirow[t]{2}{*}{ Gly $^{\#}$} & A & $<$ LOD & $<$ LOD & $0.31 \pm 0.03 *$ & $0.22 \pm<0.01$ & $<$ LOD & $<$ LOD & $<L O D$ & $0.24 \pm<0.01 *$ & $<L O D$ \\
\hline & B & $0.36 \pm 0.11 *$ & $<$ LOD & $<$ LOD & $0.27 \pm 0.01$ & $<L O D$ & $<$ LOD & $<$ LOD & $<$ LOD & $0.21 \pm 0.03 *$ \\
\hline \multirow[t]{2}{*}{ Gln } & A & $0.28 \pm<0.01$ & $0.17 \pm 0.01$ & $0.13 \pm 0.01$ & $0.22 \pm<0.01$ & $0.08 \pm<0.01$ & $0.12 \pm<0.01$ & $0.14 \pm<0.01$ & $0.18 \pm<0.01$ & $0.25 \pm 0.01$ \\
\hline & B & $0.29 \pm 0.01$ & $0.25 \pm 0.01 *$ & $0.24 \pm 0.01 *$ & $0.27 \pm 0.01 *$ & $0.07 \pm<0.01$ & $0.16 \pm<0.01^{*}$ & $0.13 \pm<0.01$ & $0.19 \pm<0.01$ & $0.27 \pm 0.01$ \\
\hline
\end{tabular}




\begin{tabular}{|c|c|c|c|c|c|c|c|c|c|c|}
\hline & B & $0.35 \pm 0.02$ & $0.38 \pm 0.02 *$ & $0.37 \pm 0.02$ & $0.58 \pm 0.01^{*}$ & $0.73 \pm 0.01 *$ & $0.86 \pm 0.02 *$ & $0.37 \pm 0.01$ & $0.44 \pm 0.02$ & $0.39 \pm 0.01 *$ \\
\hline \multirow[t]{2}{*}{ Arg } & A & $2.85 \pm 0.23$ & $2.28 \pm 0.13$ & $2.48 \pm 0.09$ & $3.07 \pm 0.26$ & $1.70 \pm 0.03$ & $1.55 \pm 0.01$ & $2.04 \pm 0.07$ & $2.72 \pm 0.15$ & $2.78 \pm 0.21$ \\
\hline & B & $3.43 \pm 0.07 *$ & $2.18 \pm 0.20$ & $2.78 \pm 0.23$ & $2.69 \pm 0.24$ & $1.77 \pm 0.05$ & $1.86 \pm 0.01 *$ & $2.18 \pm 0.08$ & $2.42 \pm 0.11$ & $3.70 \pm 0.22$ \\
\hline \multirow[t]{2}{*}{$\mathrm{Ala}^{\#}$} & A & $0.40 \pm 0.03$ & $0.66 \pm 0.02$ & $1.15 \pm 0.01 *$ & $2.28 \pm 0.08$ & $1.63 \pm 0.03^{*}$ & $0.73 \pm 0.01$ & $0.77 \pm<0.01$ & $3.42 \pm 0.08$ & $0.84 \pm 0.01$ \\
\hline & B & $0.87 \pm 0.02 *$ & $1.02 \pm 0.05 *$ & $0.91 \pm 0.03$ & $2.42 \pm 0.12$ & $1.50 \pm 0.05$ & $0.93 \pm 0.02 *$ & $0.80 \pm<0.01^{*}$ & $3.51 \pm 0.10$ & $1.17 \pm 0.02 *$ \\
\hline \multirow[t]{2}{*}{ Tyr } & A & $0.70 \pm 0.03$ & $1.05 \pm 0.02$ & $1.74 \pm 0.01 *$ & $1.35 \pm 0.01 *$ & $0.77 \pm<0.01$ & $0.84 \pm 0.01$ & $1.25 \pm 0.01$ & $1.45 \pm<0.01^{*}$ & $1.40 \pm 0.04$ \\
\hline & B & $1.46 \pm 0.05 *$ & $1.59 \pm 0.07 *$ & $1.49 \pm 0.03$ & $1.27 \pm 0.05$ & $0.96 \pm 0.01 *$ & $0.91 \pm 0.01 *$ & $1.46 \pm 0.01 *$ & $1.21 \pm 0.01$ & $1.91 \pm 0.04 *$ \\
\hline \multirow[t]{2}{*}{ Lyse } & A & $3.42 \pm 0.04$ & $2.71 \pm 0.01$ & $3.07 \pm 0.12$ & $2.91 \pm 0.14$ & $4.24 \pm<0.01$ & $3.78 \pm 0.01$ & $3.68 \pm 0.01$ & $2.84 \pm 0.04$ & $3.08 \pm 0.04$ \\
\hline & B & $3.07 \pm 0.07$ & $2.88 \pm 0.06$ & $3.85 \pm 0.03$ & $2.86 \pm 0.15$ & $3.36 \pm 0.01$ & $3.24 \pm 0.03$ & $4.21 \pm 0.04$ & $3.10 \pm 0.02$ & $3.23 \pm 0.06$ \\
\hline \multirow[t]{2}{*}{ Valø } & A & $2.08 \pm 0.01$ & $2.11 \pm 0.01$ & $2.59 \pm 0.02$ & $3.07 \pm 0.04$ & $2.09 \pm 0.02$ & $2.20 \pm 0.01$ & $2.36 \pm 0.01$ & $2.48 \pm 0.05$ & $2.70 \pm 0.03$ \\
\hline & B & $2.20 \pm 0.03$ & $1.85 \pm 0.01$ & $2.73 \pm 0.05$ & $2.80 \pm 0.01$ & $1.91 \pm 0.01$ & $2.47 \pm 0.01$ & $2.36 \pm 0.02$ & $2.39 \pm 0.03$ & $3.52 \pm<0.01$ \\
\hline \multirow[t]{2}{*}{ Mete } & $A$ & $0.20 \pm<0.01$ & $0.29 \pm 0.02$ & $0.56 \pm 0.01$ & $0.49 \pm 0.05$ & $0.40 \pm 0.01$ & $0.27 \pm 0.02$ & $0.43 \pm 0.02$ & $0.73 \pm 0.02$ & $0.41 \pm 0.03$ \\
\hline & B & $0.30 \pm 0.02$ & $0.27 \pm<0.01$ & $0.41 \pm 0.02$ & $0.45 \pm 0.01$ & $0.45 \pm 0.01$ & $0.30 \pm 0.02$ & $0.43 \pm 0.01$ & $0.61 \pm 0.03$ & $0.61 \pm 0.03$ \\
\hline \multirow[t]{2}{*}{ Trye } & A & $0.11 \pm<0.01$ & $0.07 \pm<0.01$ & $0.07 \pm<0.01$ & $0.08 \pm<0.01$ & $0.15 \pm<0.01$ & $0.13 \pm<0.01$ & $0.12 \pm<0.01$ & $0.09 \pm<0.01$ & $0.14 \pm<0.01$ \\
\hline & B & $0.12 \pm<0.01$ & $0.08 \pm<0.01$ & $0.11 \pm<0.01$ & $0.07 \pm<0.01$ & $0.12 \pm<0.01$ & $0.11 \pm<0.01$ & $0.15 \pm<0.01$ & $0.11 \pm<0.01$ & $0.12 \pm<0.01$ \\
\hline \multirow[t]{2}{*}{ Phè } & A & $1.03 \pm 0.01$ & $1.40 \pm<0.01$ & $1.50 \pm 0.01$ & $1.42 \pm 0.01$ & $1.18 \pm 0.01$ & $1.29 \pm 0.01$ & $1.33 \pm<0.01$ & $1.70 \pm 0.01$ & $1.75 \pm 0.01$ \\
\hline & B & $1.50 \pm 0.06$ & $1.36 \pm 0.04$ & $1.35 \pm 0.01$ & $1.33 \pm 0.04$ & $1.27 \pm 0.01$ & $1.57 \pm 0.01$ & $1.44 \pm 0.01$ & $1.59 \pm 0.01$ & $2.49 \pm 0.02$ \\
\hline \multirow[t]{2}{*}{ Ilè } & A & $1.66 \pm 0.03$ & $1.98 \pm 0.04$ & $2.15 \pm 0.04$ & $1.96 \pm<0.01$ & $1.60 \pm 0.02$ & $1.94 \pm 0.02$ & $1.83 \pm<0.01$ & $2.03 \pm 0.01$ & $1.99 \pm 0.02$ \\
\hline & B & $1.82 \pm 0.06$ & $1.68 \pm 0.06$ & $2.03 \pm 0.03$ & $1.81 \pm 0.05$ & $1.63 \pm 0.01$ & $2.19 \pm 0.02$ & $1.95 \pm 0.03$ & $2.13 \pm 0.02$ & $2.67 \pm 0.03$ \\
\hline Leu® & B & $2.29 \pm 0.01$ & $1.88 \pm 0.10$ & $2.48 \pm 0.05$ & $2.66 \pm 0.13$ & $2.37 \pm 0.03$ & $2.68 \pm 0.03$ & $2.55 \pm 0.04$ & $2.80 \pm 0.06$ & $3.51 \pm 0.09$ \\
\hline \multirow[t]{2}{*}{ Нyp } & A & $1.49 \pm 0.02$ & $1.09 \pm<0.01$ & $1.00 \pm<0.01$ & $1.03 \pm 0.01$ & $2.10 \pm<0.01$ & $1.89 \pm<0.01$ & $1.77 \pm<0.01$ & $0.94 \pm<0.01$ & $1.66 \pm 0.03$ \\
\hline & B & $1.50 \pm 0.01$ & $1.13 \pm 0.01$ & $1.50 \pm<0.01$ & $0.91 \pm<0.01$ & $1.58 \pm<0.01$ & $1.58 \pm 0.01$ & $2.20 \pm 0.01$ & $1.17 \pm<0.01$ & $1.49 \pm 0.03$ \\
\hline \multirow[t]{2}{*}{$\sum \mathrm{AA}$} & A & $31.2 \pm 1.75$ & $35.5 \pm 1.29$ & $39.4 \pm 2.91$ & $38.8 \pm 0.98$ & $36.6 \pm 1.25$ & $40.2 \pm 1.23$ & $37.7 \pm 0.52$ & $44.2 \pm 1.20$ & $41.3 \pm 1.56$ \\
\hline & B & $38.9 \pm 2.02 *$ & $39.6 \pm 2.02 *$ & $39.6 \pm 1.58$ & $39.9 \pm 0.19$ & $36.1 \pm 0.96$ & $39.6 \pm 0.47$ & $38.2 \pm 1.53$ & $42.3 \pm 1.89$ & $49.9 \pm 0.95^{*}$ \\
\hline \multirow[t]{2}{*}{$\%$ EAA๑ } & A & $46.7 \pm 0.25$ & $51.2 \pm 6.02$ & $47.9 \pm 2.25$ & $44.3 \pm 1.58$ & $39.2 \pm 0.89$ & $38.7 \pm 0.58$ & $49.0 \pm 1.20$ & $37.2 \pm 0.79$ & $44.5 \pm 2.03$ \\
\hline & B & $42.0 \pm 0.77$ & $49.7 \pm 2.23$ & $41.0 \pm 3.21$ & $39.9 \pm 0.19$ & $37.7 \pm 1.02$ & $37.7 \pm 0.88$ & $47.8 \pm 0.87$ & $40.2 \pm 0.58$ & $43.6 \pm 1.02$ \\
\hline \multirow[t]{2}{*}{$\%$ NEAA } & A & $29.5 \pm 0.05$ & $28.8 \pm 1.02$ & $29.9 \pm 0.95$ & $33.7 \pm 0.58$ & $36.9 \pm 1.12$ & $36.0 \pm 1.06$ & $29.4 \pm 1.22$ & $42.6 \pm 1.05$ & $33.6 \pm 1.52$ \\
\hline & B & $38.2 \pm 0.87$ & $33.8 \pm 1.47$ & $35.6 \pm 1.58$ & $39.2 \pm 1.20$ & $37.9 \pm 1.05$ & $37.1 \pm 0.87$ & $28.8 \pm 1.25$ & $40.0 \pm 1.24$ & $33.4 \pm 1.05$ \\
\hline \multirow[t]{2}{*}{$\%$ FAA $^{\#}$} & A & $23.2 \pm 1.75$ & $29.5 \pm 1.20$ & $27.4 \pm 2.02$ & $28.3 \pm 1.00$ & $32.2 \pm 0.89$ & $32.9 \pm 0.74$ & $22.7 \pm 1.40$ & $35.3 \pm 1.70$ & $22.9 \pm 1.52$ \\
\hline & B & $21.5 \pm 1.54$ & $18.6 \pm 1.87$ & $26.7 \pm 1.59$ & $26.7 \pm 0.58$ & $35.7 \pm 1.20$ & $35.2 \pm 1.02$ & $24.3 \pm 1.25$ & $32.4 \pm 1.54$ & $25.5 \pm 1.58$ \\
\hline \multirow[t]{2}{*}{ EAA/AA } & A & $0.47 \pm 0.25$ & $0.51 \pm 0.02$ & $0.48 \pm 2.03$ & $0.44 \pm<0.01$ & $0.39 \pm<0.01$ & $0.39 \pm 0.01$ & $0.49 \pm<0.01$ & $0.37 \pm<0.01$ & $0.45 \pm 0.01$ \\
\hline & B & $0.42 \pm 0.02$ & $0.50 \pm<0.01$ & $0.41 \pm 0.03$ & $0.41 \pm<0.01$ & $0.38 \pm<0.01$ & $0.38 \pm<0.01$ & $0.48 \pm 0.01$ & $0.40 \pm<0.01$ & $0.44 \pm<0.01$ \\
\hline \multirow[t]{2}{*}{ EAA/NEAA } & A & $1.58 \pm 0.05$ & $1.74 \pm 0.05$ & $1.60 \pm 0.92$ & $1.32 \pm 0.04$ & $1.06 \pm 0.02$ & $1.08 \pm 0.01$ & $1.67 \pm 0.03$ & $0.87 \pm 0.01$ & $1.32 \pm 0.05$ \\
\hline & B & $1.10 \pm 0.05$ & $1.47 \pm 0.08$ & $1.15 \pm 0.02$ & $1.04 \pm 0.02$ & $1.00 \pm 0.01$ & $1.02 \pm 0.03$ & $1.66 \pm 0.04$ & $1.01 \pm 0.05$ & $1.30 \pm 0.04$ \\
\hline \multirow[t]{2}{*}{ EAAI } & $\min$ & 12.6 (Met) & 16.7 (Met) & 25.5 (Met) & 28.2 (Met) & 24.8 (Met) & 17.0 (Met) & 27.0 (Met) & 38.2 (Met) & 25.4 (Met) \\
\hline & $\max$ & 120 (His) & 480 (His) & 246 (His) & 138 (Thr) & 94.2 (Lys) & 120 (Thr) & 303 (His) & 146 (Thr) & 254 (His) \\
\hline
\end{tabular}

Values are mean $\pm S D(n=3) ;<L O D$, lower than the Limit of Detection (see Supplement table).

EAA , essential amino acids; NEAA, non-essential amino acids; FAA ${ }^{\#}$, flavor amino acids; AA, sum of amino acids; EAAI, essential amino acid índex.

Crude protein determined by Kjeldahl method. EAAI calculated using the FAO/WHO/UNU (2007) amino acid requirement pattern.

*Significant differences $(P<0.05)$ between batch A (seaweed collection between April and July 2016) and batch B (seaweed collection between October and November 2016).

Slight variations in protein content of seaweeds in comparison to literature can be attributed to geographical origin, as well as environmental factors and seasonal effects, which may affect the nutrient storage responses. Also, different sampling methodologies and drying methods can 
seaweeds species, namely A. nodosum, U. pinnatifida and Ulva spp., exhibited inter-batch differences. For these species, higher $(P<0.05)$ contents were observed for seaweeds collected between October and November (batch B) compared to the same species collected between April and June (batch A). This observation is in line with the fact that during the autumn and winter, seaweeds possess higher ability to store nitrogen due to lower nitrogen metabolism (and degradation) of the cell (Martínez \& Rico, 2008). Inter-batch differences in the protein content of several seaweed species were also observed by other authors (Peinado et al., 2014) and could be attributed to seasonal effects, harvest location and maturity phase of the seaweed. Conversely, for C. crispus, Gracilaria sp., O. pinnatifida, Porphyra spp., F. spiralis, and S. polyschides, no significant $(P<0.05)$ differences were observed between the two collection seasons. These results are in accordance with other published data, reporting that the protein content of some seaweed species collected during mid-winter period were very similar to that reported for the same seaweed species collected in the spring (Patarra, Paiva, Neto, Lima, \& Baptista, 2011).

The protein content found in some of the seaweed species analyzed in this work - Gracilaria sp., O. pinnatifida, Porphyra spp. - was higher than that of high-protein foods such as beans (21-23\%), meats (17-23\%) and some grains like oats (13.5\%), wheat (14\%), corn (9.3\%), rice (6.7\%) and soybean (12.5\%) (INSA, 2006). These seaweeds have therefore potential use in the formulation of low-cost, protein balanced diets as an alternative to current vegetable protein sources such as legumes and cereals (Rodrigues et al., 2015), although seaweed protein digestibility has to be evaluated. The consumption of a serving portion of $1 \mathrm{~g}(\mathrm{dw})$ of C. crispus, A. nodosum, and U. pinnatifida provides an average of $0.12-$ $0.24 \mathrm{~g}$ of protein. Thus, considering the recommended daily allowance (RDA) for protein intake of $56 \mathrm{~g} / \mathrm{day}$ (men) and $46 \mathrm{~g} / \mathrm{day}$ (women) (Institute of Medicine, 2006), the dose intake ( $1 \mathrm{~g} \mathrm{dw}$ ) of these species contribute to RDA values $0.21-0.43 \%$ (men) and $0.26-0.52 \%$ (women), while $5 \mathrm{~g}(\mathrm{dw})$ of Porphyra spp. and Ulva spp furnish $0.59-1.19 \mathrm{~g}$ of proteins corresponding to a RDA contribution of $1.06-2.13 \%$ (men) and $1.28-2.59 \%$ (women).

\subsection{Total amino acid composition}

As the nutritional quality of a protein is determined by the content, proportion and availability of EAA, the amino acid profile of the Total protein fraction of the characterized seaweeds was also evaluated (Table 2). The results of the amino acids Asn and Pro are not discussed because the concentrations found in all the samples analyzed were lower than the respective LOD (Table1S). The first observation is that only

31.2-49.9g of amino acids/ $100 \mathrm{~g}$ protein content were quantified by the chromatographic analysis, suggesting an underestimation of the real amino acid content and/or an overestimation of total protein content. In fact, the real content of protein quantified by the Kjeldahl method can be overestimated by the presence of non-protein constituents, namely photosynthetic pigments, nitrate and nitrite, ammonium salts and nucleic acids (Mišurcová et al., 2014). This limitation has also been reported by other authors (Sánchez-Machado et al., 2003, Dawczynski et al., 2007). Nevertheless, a strong correlation $(r=0.761 ; P<0.05)$ was observed between the results obtained by Kjeldahl and RPHPLC methods. Comparing the three classes of seaweeds analyzed in the present study, some significant $(P<0.05)$ differences were observed: brown seaweeds had lower EAA (41.0\% protein) than red or green seaweeds, which displayed no significant differences between them (45.5 and $44.0 \%$ protein, respectively) (Table 2); however, since only one green species was available in the selected sampling sites in the NorthCentral coast of Portugal, this comparison should be made with caution. In contrast, brown seaweeds displayed higher $(P<0.05)$ non-essential amino acids (NEAA; $36.1 \%$ protein) and mean contents of Glu (6.49\% protein), Ala (1.66\% protein), Lys (3.56\% protein) and Tau ( $0.60 \%$ protein) than the red seaweeds and the green species. All the species presented high levels of Asp, Glu, Ser, His, Arg, Lys, Val, Leu and lle. The green seaweed Ulva spp. exhibited higher $(P<0.05)$ mean contents of Asp (5.32\%), Ser (7.58\% protein), His (3.59\% protein), Arg (3.24\% protein), Tyr (1.66\% protein), Val (3.11\% protein), Phe (2.12\% protein), Ile (2.33\% protein) and Leu (3.01\% protein) than the other two classes of seaweeds. In general, the results obtained in this work are within the range reported by published data (Holdt and Kraan, 2011, Paiva et al., 2014, AstorgaEspaña etal., 2016).

\subsubsection{EAAl and limiting EAA}

The essential amino acid index (EAAI) is an important factor for the evaluation of protein quality, comparing it to a high-quality reference protein (Dawczynski et al., 2007, Mišurcová et al., 2014). The most recent reference protein (FAO/WHO/,UNU, 2007) was used in this work; concentrations of EAA higher than the protein reference pattern were expressed as EAAl values higher than 100. Results (Table 2) showed that the EAAl values were in the range of $12.6-480 \%$ (red seaweeds species), 17.0-303\% (brown seaweeds) and 25.4-254\% (Ulva spp.) for different essential amino acids. Among red and brown seaweeds species, Gracilaria sp. and S. polyschides presented the highest percentage of EAA with mean contents of $49.7-51.2 \%$ and $47.8-49.0 \%$, respectively. The highest EAA found in Gracilaria sp. was His (6.20-7.20\% protein) while in S. polyschides His (3.21-4.54\% protein) and Lys (3.68-4.21\% protein) were the most abundant. These results suggest that both seaweed species have similar EAA content as other protein sources such as casein (43.6\%), leguminous plants (45.4\%) and ovalbumin (52.4\%) (Paiva et al., 2014). The EAA percentage of O. pinnatifida, Porphyra spp. and F. spiralis were $41.0-47.9 \%, 39.9-44.3 \%$ and $37.7-38.7 \%$ protein, respectively. These values were lower than those showed by Paiva et al. (2014) (41.6\%, 56.7\% and 63.5\%, respectively for O. pinnatifida, Porphyra spp. and F. spiralis), but in the same range of the EAA values reported by Sánchez-Machado et al. (2003), which were 39.5\% for Porphyra spp. and 38.5\% for $U$. pinnatifida. Overall, Trp, Met and Leu were found as the principal limiting EAA in all the evaluated species (red, brown and green seaweeds). This result is in agreement with literature data (Dawczynski et al., 2007, Astorga-España et al., 2016), that have been reporting Trp and sulfur amino acids (Met and Cys) as the limiting EAA for several species of red, brown and green seaweeds. On the other hand, and in contrast to the observed by other authors (Dawczynski et al., 2007, Matanjun et al., 2009, Mišurcová et al., 2014), Lys was detected in all the analyzed species, with EAAI scores ranging from $60.2 \%$ to $94.2 \%$. The presence of Lys is of particular interest because this EAA is frequently a limiting amino acid in animal feeds. In general, the high concentrations of EAAs in the characterized edible seaweeds from the North-Central coast of Portugal suggest their potential use as food ingredients with an interesting amino acid profile.

\subsubsection{Non-Essential amino acids}


contents ranged from $3.17 \pm 0.14 \%$ protein (C. crispus) to $8.12 \pm 0.17 \%$ protein (F. spiralis) and Asp contents varied between $3.14 \pm 0.16 \%$ protein (Gracilaria sp.) and $6.10 \pm 0.36 \%$ protein (Ulva spp.). As reported by Mišurcová et al. (2014), brown seaweeds presented highest concentration of Glu compared to red seaweed species. The high levels of flavor amino acids (FAA; Asp, Glu, Ala and Gly) explain the special taste of seaweeds and marine products (Paiva et al., 2014).

\subsubsection{The ratio of essential and non-essential amino acids}

The distribution of essential and non-essential amino acids in seaweeds proteins can be evaluated by the ratio of EAAs/NEAAs. Its lowest range (0.87-1.01) was found in the brown seaweed $U$. pinnatifida, which is in reasonable agreement with the value of 0.7 reported by Dawczynski et al. (2007). In contrast, the EAAs/NEAAs in the other seaweed species ranged from 1.00 to 1.06 (A. nodosum) to 1.47-1.74 (Gracilaria sp.), being markedly higher than values reported in literature (Dawczynski et al., 2007, Astorga-España et al., 2016), which were in the interval between 0.5 and 0.8 . These differences can be attributed to the contribution of some amino acids for both EAAs and NEAAs fractions. For instance, differently from the Astorga-España et al. (2016) study, in the present work, the amino acids His and Trp were included as contributors to the EAAs fraction, also the amino acid GIn was included as contributor to the NEAAs fraction.

\subsection{Free amino acid profile}

The free amino acid composition (g/100 g protein) of the different seaweed species is presented in Table 3 . This fraction, mostly represented by Asp, Glu, Ala and Gly, plays a crucial role in the seaweed flavour (Mišurcová et al., 2014). The fraction of free amino acid was higher $(P<0.05)$ in the brown seaweed species $(6.47-24.0 \mathrm{~g} / 100 \mathrm{~g}$ protein), followed by the analyzed green seaweed Ulva spp. $(8.39-14.0 \mathrm{~g} / 100 \mathrm{~g} \mathrm{protein)}$ and red seaweed species (3.40-13.1 g/100 g protein). The most abundant amino acids in all seaweeds tested included Lys, Thr, Glu, Asp and Pro. Glu was particularly high $(P<0.05)$ in the brown seaweed A. nodosum $(1.20-2.49 \%$ protein) and F. spiralis $(2.33-2.61 \%$ protein), while Asp was the highest free amino acid in O. pinnatifida (1.58-1.74\% protein). For F. spiralis, the relative contributions of Asp and Glu were in the range of $18.5 \%$ and $23.7 \%$ protein, respectively. This result is in agreement with other authors (Dawczynski et al., 2007, Peinado et al., 2014), who found that Asp and Glu constituted $26 \%$ of the free amino acid fraction in brown seaweeds. None of the analyzed seaweed species presented the amino acids Asn (concentrations found were lower than the LOD, Table1S). Met was only detected in Gracilaria sp. and F. spiralis while Phe was only found in F. spiralis.

Table 3. Concentrations of Free amino acids (expressed as $\mathrm{g} / 100 \mathrm{~g}$ protein) for different types of seaweeds collected in the North-Central coast of Portugal.

\begin{tabular}{|c|c|c|c|c|c|c|c|c|c|c|}
\hline & & Red & & & & Brown & & & & Green \\
\hline & batch & C. crispus & Gracilariasp. & O. pinnatifida & Porphyra spp. & A. nodosum & F.spiralis & S. polyschides & U. pinnatifida & Ulva spp. \\
\hline \multirow[t]{2}{*}{$\mathrm{Asp}^{\#}$} & A & $0.24 \pm<0.01$ & $0.67 \pm<0.01$ & $1.74 \pm 0.02$ & $0.14 \pm<0.01$ & $0.56 \pm<0.01$ & $1.68 \pm 0.04$ & $0.26 \pm<0.01$ & $0.36 \pm<0.01$ & $0.39 \pm<0.01$ \\
\hline & B & $0.29 \pm<0.01$ & $0.40 \pm<0.01 *$ & $1.58 \pm 0.03$ & $0.20 \pm<0.01^{*}$ & $0.88 \pm<0.01 *$ & $1.23 \pm<0.01^{*}$ & $0.70 \pm<0.01^{*}$ & $0.35 \pm<0.01$ & $0.34 \pm 0.01$ \\
\hline \multirow[t]{2}{*}{$\mathrm{Glu}^{\#}$} & A & $0.64 \pm 0.01$ & $0.28 \pm<0.01$ & $0.31 \pm 0.01$ & $0.54 \pm<0.01$ & $2.49 \pm<0.01 *$ & $2.33 \pm 0.06$ & $0.88 \pm<0.01$ & $0.71 \pm 0.01$ & $0.58 \pm<0.01$ \\
\hline & B & $0.69 \pm 0.01$ & $0.54 \pm<0.01 *$ & $0.51 \pm 0.01 *$ & $0.82 \pm 0.01 *$ & $1.20 \pm 0.01$ & $2.61 \pm 0.08$ & $1.46 \pm 0.01 *$ & $0.97 \pm 0.01 *$ & $0.76 \pm 0.01$ \\
\hline \multirow[t]{2}{*}{ Ser } & A & $0.13 \pm<0.01 *$ & $<$ LOD & $<$ LOD & $<$ LOD & $0.13 \pm<0.01 *$ & $1.68 \pm 0.02 *$ & $0.37 \pm 0.01 *$ & $0.07 \pm<0.01$ & $0.21 \pm<0.01 *$ \\
\hline & B & $<$ LOD & $<$ LOD & $<$ LOD & $<$ LOD & $<$ LOD & $<$ LOD & $<$ LOD & $<$ LOD & $0.02 \pm<0.01$ \\
\hline \multirow[t]{2}{*}{ Thre } & A & $0.89 \pm 0.01$ & $0.46 \pm 0.02$ & $1.31 \pm 0.05 *$ & $1.32 \pm 0.06$ & $2.24 \pm 0.01$ & $0.88 \pm 0.04$ & $2.04 \pm 0.05$ & $1.28 \pm 0.07$ & $2.11 \pm 0.08^{*}$ \\
\hline & B & $1.96 \pm 0.10 *$ & $2.72 \pm 0.03^{*}$ & $0.83 \pm 0.02$ & $1.62 \pm 0.16^{*}$ & $2.43 \pm<0.01$ & $1.09 \pm 0.03$ & $4.57 \pm 0.08^{*}$ & $2.34 \pm 0.09 *$ & $0.02 \pm<0.01$ \\
\hline \multirow[t]{2}{*}{ Hise } & A & $0.12 \pm<0.01^{*}$ & $<$ LOD & $0.06 \pm 0.01$ & $<$ LOD & $<$ LOD & $0.57 \pm<0.01^{*}$ & $7.40 \pm 0.07 *$ & $1.47 \pm 0.09$ & \\
\hline & B & $<$ LOD & $0.25 \pm 0.02 *$ & $<$ LOD & $<L O D$ & $<L O D$ & $<$ LOD & $4.49 \pm 0.10$ & $1.30 \pm 0.04$ & $4.00 \pm 0.06 *$ \\
\hline \multirow[t]{2}{*}{$\mathrm{Gly}^{\#}$} & A & $0.10 \pm<0.01$ & $0.03 \pm<0.01$ & $0.06 \pm 0.01$ & $0.08 \pm<0.01$ & $0.11 \pm<0.01$ & $<L O D$ & $0.01 \pm<0.01$ & $0.24 \pm<0.01^{*}$ & $0.36 \pm<0.01$ \\
\hline & B & $0.21 \pm<0.01$ & $0.02 \pm<0.01$ & $<$ LOD & $0.10 \pm<0.01$ & $0.10 \pm<0.01$ & $2.84 \pm<0.01 *$ & $0.08 \pm<0.01$ & $<L O D$ & $2.11 \pm 0.01 *$ \\
\hline \multirow[t]{2}{*}{ Gln } & A & $0.04 \pm<0.01$ & $0.15 \pm<0.01^{*}$ & $0.95 \pm 0.01 *$ & $0.02 \pm<0.01$ & $3.06 \pm 0.01^{*}$ & $0.04 \pm<0.01$ & $0.31 \pm<0.01$ & $0.18 \pm<0.01$ & $0.03 \pm<0.01$ \\
\hline & B & $0.04 \pm<0.01$ & $0.08 \pm<0.01$ & $0.18 \pm<0.01$ & $0.01 \pm<0.01$ & $2.83 \pm<0.01$ & $2.84 \pm<0.01^{*}$ & $0.66 \pm 0.01 *$ & $0.19 \pm 0.01$ & $0.20 \pm<0.01 *$ \\
\hline \multirow[t]{2}{*}{ Tau } & A & $0.02 \pm<0.01$ & $0.02 \pm<0.01$ & $0.04 \pm<0.01$ & $0.05 \pm<0.01$ & $0.58 \pm<0.01^{*}$ & $0.25 \pm 0.01^{*}$ & $0.03 \pm<0.01$ & $0.65 \pm 0.02^{*}$ & $0.08 \pm<0.01$ \\
\hline & B & $0.01 \pm<0.01$ & $<L O D$ & $0.29 \pm<0.01^{*}$ & $0.12 \pm<0.01^{*}$ & $0.42 \pm<0.01$ & $<L O D$ & $<$ LOD & $0.44 \pm 0.02$ & $0.10 \pm<0.01$ \\
\hline \multirow[t]{2}{*}{ Arg } & A & $0.24 \pm<0.01$ & $0.04 \pm<0.01$ & $0.03 \pm<0.01$ & $0.03 \pm<0.01$ & $0.10 \pm<0.01$ & $0.59 \pm 0.02$ & $0.25 \pm 0.01$ & $2.72 \pm 0.15$ & $0.07 \pm<0.01$ \\
\hline & B & $0.29 \pm<0.01$ & $0.23 \pm 0.01 *$ & $0.03 \pm<0.01$ & $0.04 \pm<0.01$ & $0.10 \pm<0.01$ & $0.72 \pm 0.01^{*}$ & $0.36 \pm<0.01$ & $2.42 \pm 0.11$ & $0.06 \pm<0.01$ \\
\hline
\end{tabular}




\begin{tabular}{|c|c|c|c|c|c|c|c|c|c|c|}
\hline & B & $0.60 \pm<0.01^{*}$ & $2.20 \pm<0.01^{*}$ & $0.29 \pm<0.01 *$ & $1.41 \pm<0.01^{*}$ & $0.81 \pm<0.01$ & $0.21 \pm<0.01$ & $<L O D$ & $2.97 \pm 0.01^{*}$ & $0.04 \pm<0.01$ \\
\hline \multirow{2}{*}{ Tyr } & A & $0.03 \pm<0.01$ & $0.02 \pm<0.01$ & $0.02 \pm<0.01$ & $0.01 \pm<0.01$ & $0.04 \pm<0.01$ & $0.27 \pm<0.01^{*}$ & $0.14 \pm<0.01 *$ & $0.03 \pm<0.01$ & $0.07 \pm<0.01 *$ \\
\hline & B & $1.12 \pm<0.01 *$ & $4.08 \pm 0.01 *$ & $0.72 \pm<0.01 *$ & $0.01 \pm<0.01$ & $0.01 \pm<0.01$ & $0.14 \pm<0.01$ & $0.08 \pm<0.01$ & $0.02 \pm<0.01$ & $0.03 \pm<0.01$ \\
\hline \multirow[t]{2}{*}{ Lyse } & A & $0.67 \pm 0.01$ & $0.54 \pm<0.01$ & $0.87 \pm 0.03 *$ & $0.55 \pm<0.01$ & $1.43 \pm<0.01$ & $1.21 \pm<0.01$ & $1.14 \pm<0.01$ & $0.67 \pm 0.01$ & $1.17 \pm 0.02 *$ \\
\hline & B & $0.69 \pm<0.01$ & $1.27 \pm 0.04 *$ & $0.61 \pm 0.01$ & $0.57 \pm<0.01$ & $1.85 \pm<0.01^{*}$ & $3.55 \pm 0.01 *$ & $1.24 \pm<0.01$ & $0.71 \pm<0.01$ & $0.85 \pm<0.01$ \\
\hline \multirow[t]{2}{*}{ Valø } & A & $0.03 \pm<0.01$ & $0.06 \pm<0.01$ & $0.13 \pm<0.01^{*}$ & $0.03 \pm<0.01$ & $0.02 \pm<0.01$ & $0.71 \pm<0.01^{*}$ & $0.31 \pm<0.01 *$ & $0.02 \pm<0.01$ & $0.21 \pm 0.01$ \\
\hline & B & $0.02 \pm<0.01$ & $0.26 \pm<0.01 *$ & $0.02 \pm<0.01$ & $0.01 \pm<0.01$ & $0.02 \pm<0.01$ & $0.18 \pm 0.01$ & $0.09 \pm<0.01$ & $0.01 \pm<0.01$ & $0.07 \pm<0.01$ \\
\hline \multirow[t]{2}{*}{ Metø } & A & $<$ LOD & $<$ LOD & $<$ LOD & $<$ LOD & $<$ LOD & $0.09 \pm 0.01$ & $<$ LOD & $<$ LOD & $<$ LOD \\
\hline & B & $<$ LOD & $0.09 \pm<0.01$ & $<$ LOD & $<$ LOD & $<$ LOD & $<$ LOD & $<$ LOD & $<$ LOD & $<$ LOD \\
\hline \multirow[t]{2}{*}{ Trye } & A & $0.16 \pm<0.01$ & $0.08 \pm<0.01$ & $0.08 \pm<0.01$ & $0.05 \pm<0.01$ & $0.29 \pm<0.01$ & $0.04 \pm<0.01$ & $0.24 \pm<0.01$ & $<$ LOD & $0.17 \pm<0.01$ \\
\hline & B & $0.44 \pm<0.01 *$ & $0.09 \pm<0.01$ & $0.24 \pm<0.01^{*}$ & $0.06 \pm<0.01$ & $0.24 \pm<0.01$ & $0.68 \pm<0.01 *$ & $0.22 \pm<0.01$ & $0.11 \pm<0.01$ & $0.13 \pm<0.01$ \\
\hline \multirow[t]{2}{*}{ Phè } & A & $<$ LOD & $<$ LOD & $<$ LOD & $<$ LOD & $<$ LOD & $0.41 \pm<0.01^{*}$ & $<L O D$ & $<$ LOD & $<$ LOD \\
\hline & B & $<$ LOD & $<$ LOD & $<$ LOD & $<$ LOD & $<$ LOD & $<$ LOD & $<$ LOD & $<$ LOD & $<$ LOD \\
\hline \multirow[t]{2}{*}{ Ilè } & A & $<$ LOD & $0.01 \pm<0.01$ & $0.06 \pm<0.01$ & $<$ LOD & $0.02 \pm<0.01$ & $0.62 \pm<0.01 *$ & $0.11 \pm<0.01^{*}$ & $0.01 \pm<0.01$ & $0.18 \pm<0.01 *$ \\
\hline & B & $0.01 \pm<0.01$ & $0.01 \pm<0.01$ & $0.01 \pm<0.01$ & $<$ LOD & $0.01 \pm<0.01$ & $0.09 \pm<0.01$ & $0.02 \pm<0.01$ & $0.02 \pm<0.01$ & $0.03 \pm<0.01$ \\
\hline \multirow[t]{2}{*}{ Leu® } & A & $0.01 \pm<0.01$ & $0.03 \pm<0.01$ & $0.05 \pm<0.01$ & $0.02 \pm<0.01$ & $0.07 \pm<0.01$ & $0.76 \pm 0.01^{*}$ & $0.23 \pm<0.01 *$ & $0.03 \pm<0.01$ & $0.16 \pm<0.01 *$ \\
\hline & B & $0.02 \pm<0.01$ & $0.01 \pm<0.01$ & $0.03 \pm<0.01$ & $0.02 \pm<0.01$ & $0.09 \pm<0.01$ & $0.23 \pm<0.01$ & $0.09 \pm \pm<0.01$ & $0.04 \pm<0.01$ & $0.07 \pm<0.01$ \\
\hline \multirow[t]{2}{*}{ Hyp } & A & $0.19 \pm<0.01$ & $0.18 \pm<0.01$ & $0.20 \pm<0.01$ & $0.20 \pm<0.01$ & $0.52 \pm<0.01$ & $0.60 \pm<0.01$ & $0.40 \pm<0.01$ & $0.24 \pm<0.01$ & $0.35 \pm<0.01$ \\
\hline & B & $0.22 \pm<0.01$ & $0.13 \pm<0.01$ & $0.21 \pm<0.01$ & $0.20 \pm<0.01$ & $0.66 \pm<0.01$ & $1.30 \pm<0.01^{*}$ & $0.44 \pm<0.01$ & $0.26 \pm<0.01$ & $0.29 \pm<0.01$ \\
\hline Pro & B & $0.96 \pm<0.01$ & $0.63 \pm 0.05$ & $0.85 \pm 0.03$ & $<$ LOD & $<$ LOD & $0.44 \pm 0.10^{*}$ & $1.68 \pm 0.06$ & $1.16 \pm<0.01 *$ & $1.38 \pm 0.02 *$ \\
\hline \multirow[t]{2}{*}{$\Sigma \mathrm{AA}$} & A & $4.38 \pm 0.02$ & $3.40 \pm 0.08$ & $6.69 \pm 0.12$ & $4.05 \pm 0.03$ & $13.3 \pm 0.08$ & $13.0 \pm 0.04$ & $16.1 \pm 0.08$ & $6.47 \pm 0.02$ & $8.39 \pm 0.02$ \\
\hline & B & $7.28 \pm 0.06^{*}$ & $13.1 \pm 0.10^{*}$ & $6.83 \pm 0.09$ & $5.21 \pm 0.08$ & $11.6 \pm 0.06$ & $24.0 \pm 0.12^{*}$ & $16.2 \pm 0.03$ & $10.8 \pm 0.06 *$ & $14.0 \pm 0.08 *$ \\
\hline \multirow[t]{2}{*}{$\%$ EAA๑ } & A & $43.4 \pm 0.08$ & $35.3 \pm 0.87$ & $37.8 \pm 0.11$ & $48.9 \pm 0.12$ & $30.8 \pm 0.11$ & $39.5 \pm 0.05$ & $71.4 \pm 0.12$ & $32.0 \pm 0.10$ & $46.6 \pm 0.08$ \\
\hline & B & $43.0 \pm 0.05$ & $37.4 \pm 0.08$ & $25.5 \pm 0.09$ & $44.3 \pm 0.09$ & $39.9 \pm 0.08$ & $17.1 \pm 0.04$ & $67.8 \pm 0.08$ & $31.0 \pm 0.08$ & $61.9 \pm 0.10$ \\
\hline \multirow[t]{2}{*}{$\%$ NEAA } & A & $45.9 \pm 0.07$ & $38.4 \pm 0.10$ & $31.9 \pm 0.17$ & $41.0 \pm 0.12$ & $56.3 \pm 0.08$ & $35.2 \pm 0.11$ & $23.0 \pm 0.07$ & $57.8 \pm 0.09$ & $41.7 \pm 0.05$ \\
\hline & B & $49.6 \pm 0.06$ & $58.5 \pm 0.52$ & $43.7 \pm 0.08$ & $45.2 \pm 0.08$ & $42.5 \pm 0.10$ & $77.6 \pm 0.06$ & $24.4 \pm 0.05$ & $62.4 \pm 0.16$ & $32.4 \pm 0.08$ \\
\hline \multirow[t]{2}{*}{$\% \mathrm{FAA}^{\#}$} & A & $20.2 \pm 0.04$ & $28.0 \pm 0.09$ & $30.8 \pm 0.14$ & $40.9 \pm 0.09$ & $32.8 \pm 0.07$ & $40.9 \pm 0.12$ & $7.25 \pm 0.02$ & $51.2 \pm 0.09$ & $11.9 \pm 0.08$ \\
\hline & B & $21.6 \pm 0.02$ & $24.8 \pm 0.58$ & $39.1 \pm 0.09$ & $46.9 \pm 0.15$ & $26.6 \pm 0.04$ & $46.9 \pm 0.08$ & $13.3 \pm 0.04$ & $39.8 \pm 0.08$ & $8.17 \pm 0.02$ \\
\hline \multirow[t]{2}{*}{ EAA/AA } & A & $0.43 \pm 0.02$ & $0.35 \pm 0.04$ & $0.38 \pm 0.02$ & $0.49 \pm 0.04$ & $0.40 \pm 0.02$ & $0.49 \pm 0.02$ & $0.71 \pm 0.02$ & $0.32 \pm 0.02$ & $0.47 \pm 0.02$ \\
\hline & B & $0.43 \pm 0.04$ & $0.37 \pm 0.05$ & $0.26 \pm 0.03$ & $0.44 \pm 0.04$ & $0.17 \pm 0.05$ & $0.44 \pm 0.05$ & $0.68 \pm<0.01$ & $0.31 \pm 0.05$ & $0.62 \pm 0.04$ \\
\hline \multirow[t]{2}{*}{ EAA/NEAA } & A & $0.95 \pm 0.08$ & $0.92 \pm 0.07$ & $1.19 \pm 0.18$ & $1.19 \pm 0.08$ & $1.12 \pm 0.05$ & $1.19 \pm 0.08$ & $3.10 \pm 0.08$ & $0.55 \pm 0.04$ & $1.12 \pm 0.04$ \\
\hline & B & $0.87 \pm 0.07$ & $0.64 \pm 0.08$ & $0.58 \pm 0.05$ & $0.98 \pm 0.05$ & $0.22 \pm 0.04$ & $0.87 \pm 0.07$ & $2.78 \pm 0.03$ & $0.50 \pm 0.07$ & $1.91 \pm 0.05$ \\
\hline
\end{tabular}

Values are mean $\pm S D(n=3) ;<L O D$, lower than the Limit of Detection (see Supplement table).

EAA•, essential amino acids; NEAA, non-essential amino acids; FAA \#, flavor amino acids; AA, sum of amino acids; EAAI, essential amino acid índex.

Crude protein determined by Kjeldahl method. EAAl calculated using the FAO/WHO/UNU (2007) amino acid requirement pattern.

*Significant differences $(P<0.05)$ between batch A (seaweed collection between April and July 2016) and batch B (seaweed collection between October and November 2016).

\subsection{Commercial seaweeds amino acid composition}

The total and free amino acid composition (expressed as $\mathrm{g} / 100 \mathrm{~g}$ protein) of the commercial seaweeds analyzed in this study is presented in Table 4. The protein content found for aquacultured C. crispus, Porphyra sp., Palmaria palmata and Ulva sp. dried seaweeds (16.4, 30.7, 13.9 and $15.3 \mathrm{~g} / 100 \mathrm{~g} \mathrm{dw}$, respectively; Table 4) was not in agreement with the product's label (15.7, 27.6, 17.2 and $16.3 \mathrm{~g} / 100 \mathrm{~g} \mathrm{dw}$, respectively, Table 1). Concerning the Total amino acid composition, results show that Lys, Ser, Glu and Asp were the most abundant amino acids in the tested seaweeds, with mean contents ranging between 5.28 and 14.3, 4.50-17.0, 1.81-14.2 and 5.59-13.5 g/100 g protein, respectively. The fraction of free amino acid $(\Sigma \mathrm{AA})$ was higher $(P<0.05)$ for the brown seaweeds species $A$. nodosum $(34.4 \pm 0.10 \mathrm{~g} / 100 \mathrm{~g}$ protein) and $F$. vesiculosus 
and $P$. palmata $(21.4 \pm 0.07 \mathrm{~g} / 100 \mathrm{~g}$ protein). Wild C. crispus exhibited a significantly $(P<0.05)$ higher free amino acid content than the same species from aquaculture origin. As observed for the seaweeds harvested in the North-Central coast of Portugal, the most abundant amino acids in the characterized commercial seaweeds were Lys, Thr, Glu, Asp, His, Hyp and Pro; the amino acid Asn was not detected (concentrations found < LOD, Table 1S). Comparing the amino acid composition of the commercial seaweeds (Table 4) with the respective seaweeds species harvested in the North-Central coast of Portugal (Table 2), results showed that the protein content was similar (except for the species C. crispus, U. pinnatifida and Ulva spp.), while significant differences $(P<0.05)$ were observed in terms of the mean concentrations of Asp, Glu, Lys and EAA. Except for the red species $C$. crispus and Porphyra sp., commercial seaweeds exhibited higher $(P<0.05)$ levels of \% EAA (45.7\% for $A$. nodosum; $45.8 \%$ for U. pinnatifida and 55.1\% for aquacultured $U l v a$ spp.) but lower $(P<0.05)$ contents of \% NEAA (31.6\%, 31.1\% and $26.8 \%$ for A. nodosum; U. pinnatifida and cultured Ulva spp., respectively) and \% FAA (22.4\%; $26.9 \% 13.0 \%$ for A. nodosum; U. pinnatifida and aquacultured Ulva spp., respectively). Concerning the Total amino acid fraction, the commercial wild and aquaculture $C$. crispus seaweeds presented a similar pattern in terms of sum of amino acids ( 66.1 and $63.4 \mathrm{~g} / 100 \mathrm{~g}$ protein, respectively), \% EAA (48.8\% and $47.9 \%), \%$ NEAA (16.7\% and $18.4 \%)$ and \% FAA (21.5\% and $21.8 \%)$. Regarding the Free amino acid fraction, the wild C. crispus seaweed presented higher \% NEAA $(36.9 \%, P<0.05)$ but lower FAA $(3.46 \%, P<0.05)$ than the $C$. crispus seaweed from aquaculture.

Table 4. Protein content (g/100 g) and Total and Free amino acid (expressed as g/100 g protein) of commercial European seaweeds.

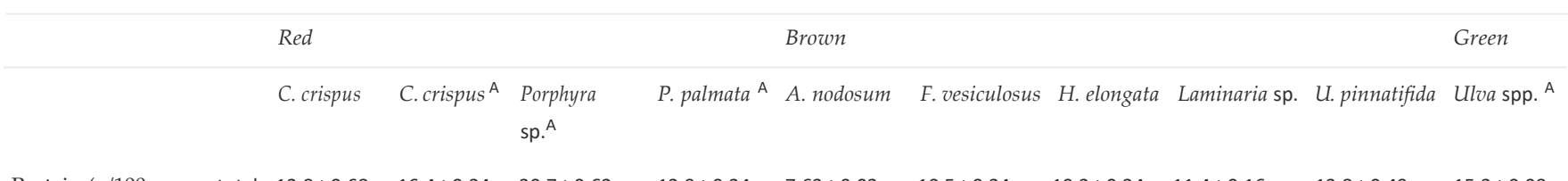

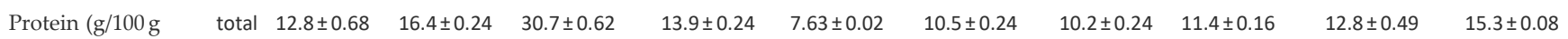
$\mathrm{dw})$

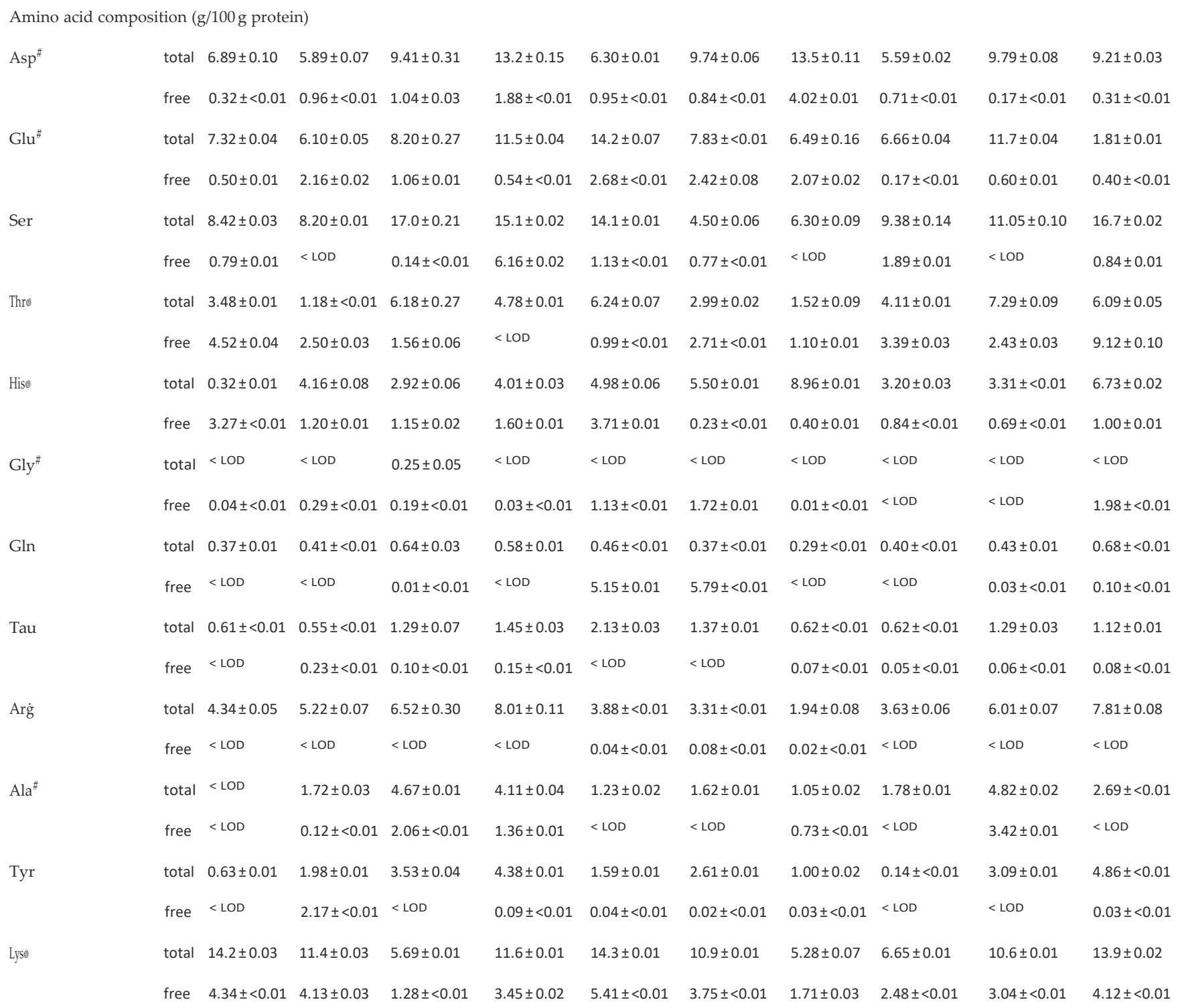




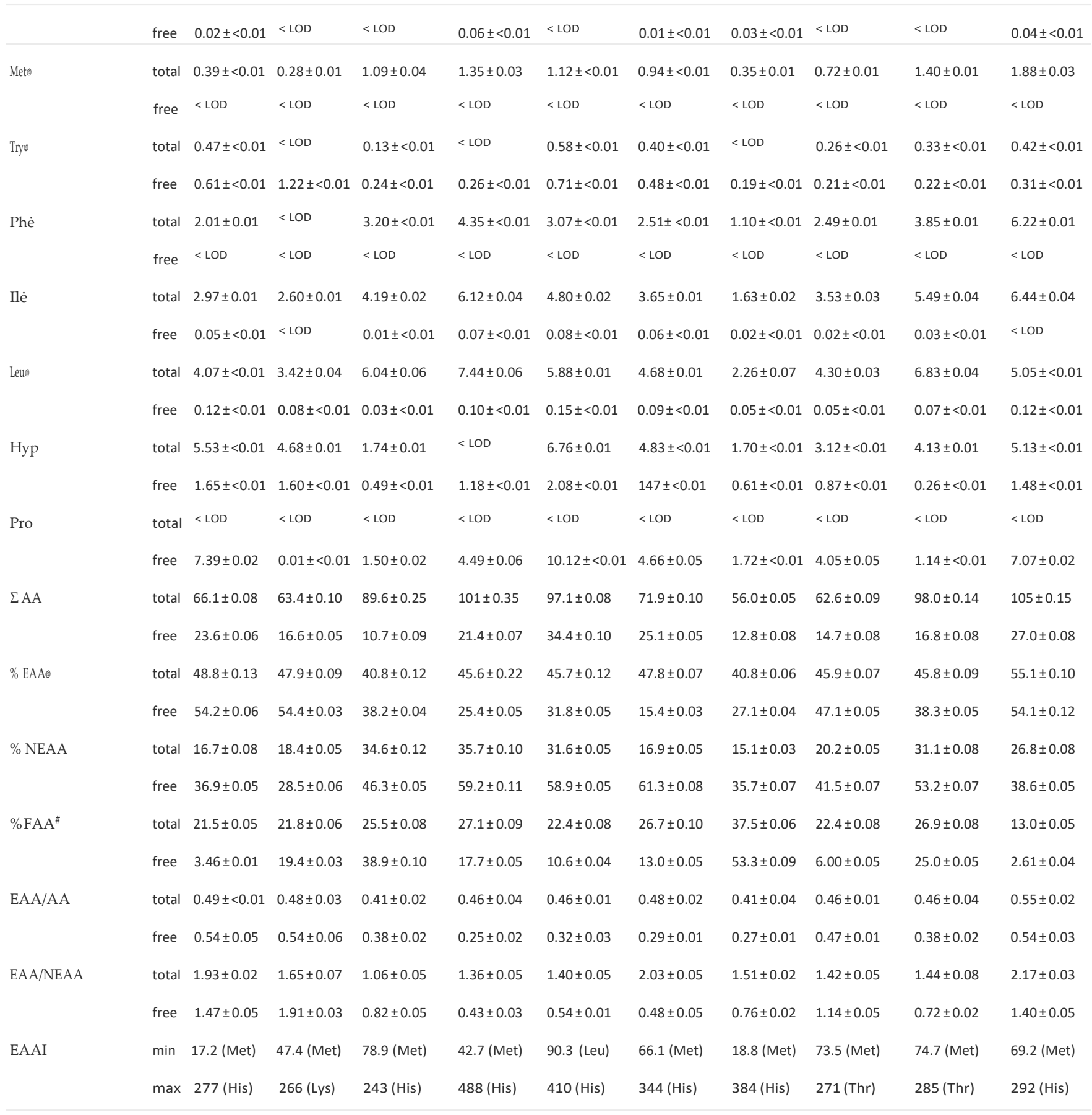

Values are mean $\pm S D(n=3) ;<L O D$, lower than the Limit of Detection (see Supplement table).

EAA ,essential amino acids; NEAA, non-essential amino acids; FAA \#, flavor amino acids; $\Sigma A A$, sum of amino acids; EAAl, essential amino acid índex.

Crude protein determined by Kjeldahl method. EAAI calculated using the FAO/WHO/UNU (2007) amino acid requirement pattern.

Aseaweeds from Aquaculture origin.

\subsection{Contribution of seaweed EAAs to RDIs}

The results of the contribution of fresh and commercial seaweeds to the RDIs of EAAs are shown in Fig. 2. With the exception of C. crispus species, the seaweeds collected in the North-Central coast of Portugal presented lower EAAs contributions to RDIs compared to commercial species (both wild and aquacultured). Several factors could explain the differences observed between fresh and commercial seaweeds, including the geographical location, habitat, season, water quality, temperature and nutrient content of the growth medium (Peinado et al., 2014). 

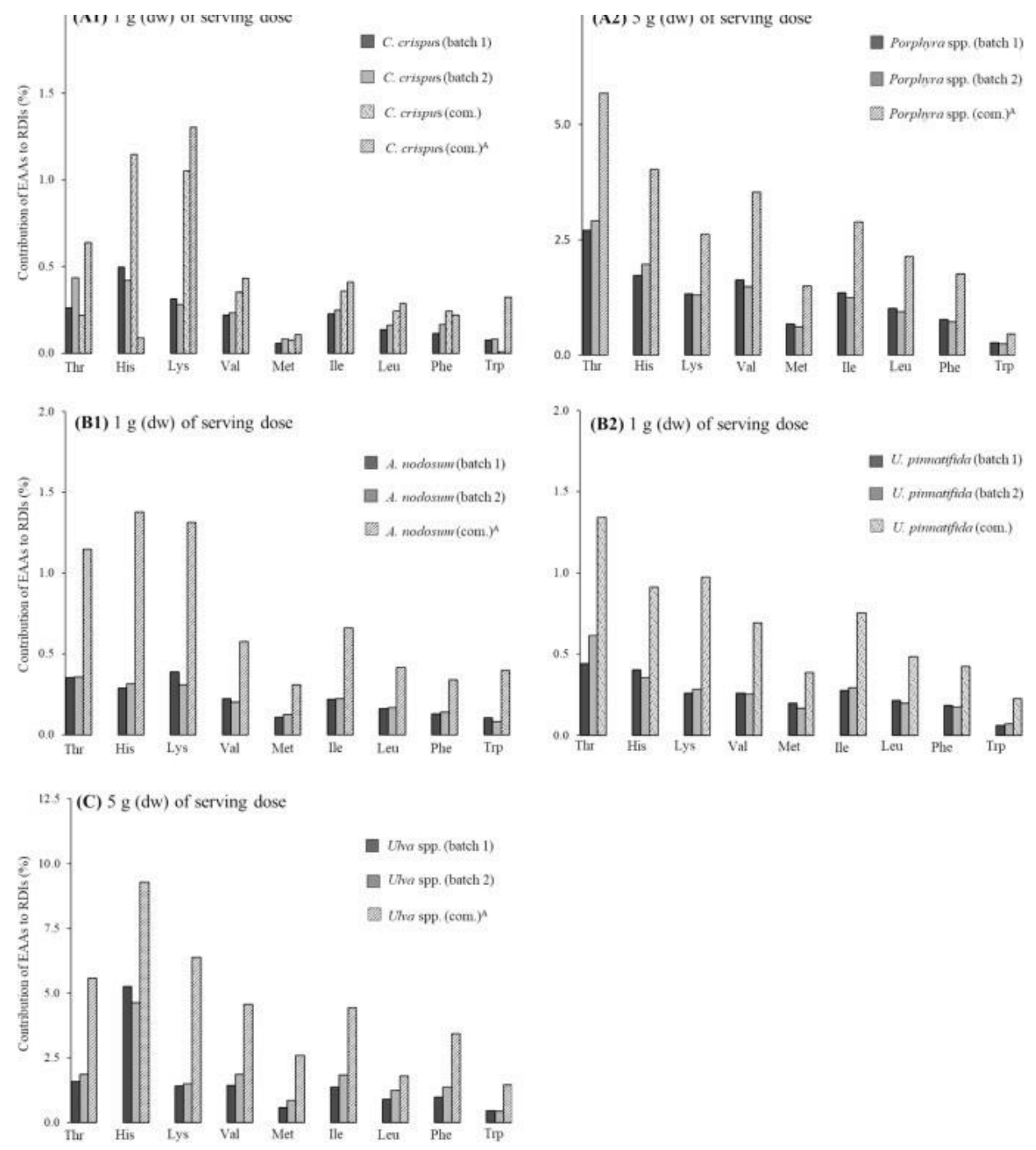

Fig. 2. Contribution of essential amino acids (EAAs) to recommended dietary intakes (RDIs, \%) of adults (70 kg body weight) by ingestion of (A1-A2) 1-5 g (dw) of red seaweeds, (B1-B2) $1 \mathrm{~g}(\mathrm{dw})$ of brown species and (C) $5 \mathrm{~g}(\mathrm{dw})$ of green seaweeds.(com.)- Indicates wild commercial species; (com.) $)^{\mathrm{A}}$ - Indicates aquacultured commercial species.

In general Met and Trp were the lowest contributors to RDIs from all EAAs in fresh and commercial seaweeds (which corresponds to the limiting EAA in these samples), while Thr, His and Lys were established as the highest EAAs contributors. In the case of C. crispus (red seaweed), and except for His and Lys, the contribution of EAAs for RDIs was similar for fresh and commercial seaweeds. An edible dose of $1 \mathrm{~g}$ $(\mathrm{dw}$ ) of fresh C. crispus (batch 1 and 2) contributed to RDIs in the range of $0.06-0.08 \%$ (Met) to $0.42-0.50 \%$ (His), being similar to the respective contribution of the wild commercial C. crispus in terms of Met $(0.08 \%)$, but significantly lower $(P<0.05)$ for His $(1.15 \%)$. Aquacultured and wild commercial C. crispus seaweeds contributed differently $(P<0.05)$ for Thr, His, Lys and Trp RDIs. For Porphyra spp., all EAAs from commercial samples presented greater $(P<0.05)$ proportion $(0.46 \%(\operatorname{Trp})-5.68 \%(\mathrm{Thr})$ RDls based on $5 \mathrm{~g}(\mathrm{dw}))$ when compared to the samples collected within this study $(0.25 \%(\operatorname{Trp})-2.91 \%(T h r))$. A similar pattern was obtained for the two brown seaweeds $A$. nodosum and $U$. pinnatifida, and for Ulva spp. (green seaweed). An edible dose of $1 \mathrm{~g}(\mathrm{dw}$ ) of fresh A. nodosum contributed to RDIs in the range of $0.08 \%$ (Trp) to $0.39 \%$ (Lys), being lower than the respective contributions of the commercial form $(0.40 \%$ (Trp) and $1.31 \%$ (Lys)). The RDIs contributions of $1 \mathrm{~g}$ (dw) of $U$. pinnatifida ranged from $0.06 \%$ (Trp) to $0.62 \%$ (Thr); those values were respectively $0.23 \%$ and $1.34 \%$ for the commercial species. The green seaweed Ulva spp. exhibited the greatest His contribution to RDIs among all the seaweeds analyzed; an edible dose of $5 \mathrm{~g}(\mathrm{dw})$ represented RDIs contribution ranging from 4.63 to $5.26 \%$ (batch 1 and 2 of fresh seaweed) to $9.28 \%$ (commercial seaweed).

\section{Conclusions}

The present study reports for the first time the influence of seasonal variations on the Total and Free amino acid composition (and its potential contribution to RDIs) of the seaweeds species C. crispus, Gracilaria sp., O. pinnatifida, Porphyra spp., A. nodosum, F. spiralis, S. polyschides, U. pinnatifida and Ulva spp., collected in the North-Central coast of Portugal. Results showed that all seaweeds are rich sources of proteins and contain all the EAAs at various concentrations. Regarding the influence of seasonal variations on the protein quality, only some species presented inter-batch differences. Moreover, most of the investigated seaweed species presented a similar amino acid distribution profile to those of commercial European seaweeds on the market, although differences in individual and total EAA concentrations were detected. Allied with seawater quality control and environmental impact of seaweed harvesting, efforts should be done to potentially explore the seaweeds 
consumption and for animal feed.

\section{Acknowledgments}

This work received financial support from project iCanSea - Conservas com macroalgas para diferenciação nutricional e sensorial, by the consortium La Gondola, Instituto Superior de Engenharia do Instituto Politécnico do Porto (ISEP) and WEDOTECH, sponsored by Portugal 2020 under the Programa Operacional Competitividade e Internacionalização (Ref.3171/Portugal 2020). The Fundação para a Ciência e a Tecnologia (FCT) and the FEDER, under Programme PT2020 (Project UID/QUI/50006/ 2013) and the project Qualidade e Segurança Alimentar - uma abordagem (nano)tecnológica (NORTE-01-0145-FEDER-000011) are also acknowledged for the financial funding.

\section{References}

Agostoni et al., 2014 C. Agostoni, R. Berni Canani, S. Fairweather-Tait, M. Heinonen, H. Korhonen, S. La Vieille Scientific opinion on dietary reference values for iodine. Panel on Dietetic Products, Nutrition and Allergies EFSA Journal, 12 (5) (2014), p. 3660

Astorga-España et al., 2016 M.S. Astorga-España, B. Rodríguez-Galdón, E.M. Rodríguez-Rodríguez, C. Díaz-Romero Amino acid content in seaweeds from the Magellan Straits (Chile)

Bleakley and Hayes, 2017 S. Bleakley, M. Hayes

Algal proteins: extraction, application, and challenges concerning production Foods, 6 (5) (2017), p. 33

Černá, 2011 M. Černá

Chapter 24 - Seaweed proteins and amino acids as nutraceuticals

S.-.K. Kim, S. Taylor (Eds.), Advances in Food and Nutrition Research, vol. 64, Academic Press (2011), pp. 297-312

Dawczynski et al., 2007 C. Dawczynski, R. Schubert, G. Jahreis

Amino acids, fatty acids, and dietary fibre in edible seaweed products

Food Chemistry, 103 (3) (2007), pp. 891-899

Déléris et al., 2016 P. Déléris, H. Nazih, J.M. Bard

Chapter 10 - Seaweeds in Human health

J. Fleurence, I. Levine (Eds.), Seaweed in Health and Disease Prevention, Academic Press, San Diego (2016), pp. 319-367

Fleurence et al., 2018 J. Fleurence, M. Morançais, J. Dumay

Chapter 9 - Seaweed proteins 
Food and Agriculture Organization, 1991 Food and Agriculture Organization World Health Organization. Protein Quality Evaluation Report of Joint FAO/WHO Expert Consultation 1991 FAO: Rome, Italy.

Friedman, 1996 M. Friedman

Nutritional value of proteins from different food sources: a review

Journal of Agricultural and Food Chemistry, 44 (1996), pp. 6-29

Gaithersburg and AoA, 2000 Gaithersburg M, Communities AoA. (2000). Official methods of analysis of AOAC International, 7th edition, USA.

Heems et al., 1998 D. Heems, G. Luck, C. Fraudeau, E. Verette

Fully automated precolumn derivatization, on-line dialysis and high-performance liquid chromatographic analysis of amino acids in food, beverages and feedstuff

Journal of Chromatography A, 798 (1998), pp. 9-17

Holdt and Kraan, 2011 S.L. Holdt, S. Kraan

Bioactive compounds in seaweed: Functional food applications and legislation

Journal of Applied Phycology, 23 (3) (2011), pp. 543-597

Institute of Medicine, 2006 Institute of Medicine

Dietary Reference Intakes: The essential guide to nutrient requirements

The National Academies Press, Washington D.C (2006)

Kadam et al., 2017 S.U. Kadam, C. Álvarez, B.K. Tiwari, C.P. O'Donnell

Extraction and characterization of protein from Irish brown seaweed Ascophyllum nodosum

Food Research International, 99 (2017), pp. 1021-1027

Makkar et al., 2016 H.P.S. Makkar, G. Tran, V. Heuzé, S. Giger-Reverdin, M. Lessire, F. Lebas, P. Ankers

Seaweeds for livestock diets: A review

Animal Feed Science and Technology, 212 (2016), pp. 1-17

Malmer and Schroeder, 1990 M.F. Malmer, L.A. Schroeder

Amino acid analysis by high-performance liquid chromatography with methanesulfonic acid hydrolysis and 9-

fluorenylmethylchloroformate derivatization

Journal of Chromatography A, 514 (1990), pp. 227-239

Mare, 2014 D. Mare Study on deepening understanding of potential blue growth in the EU member states on Europe's Atlantic arc 2014 Rotterdam/Brussels.

Martínez and Rico, 2008 B. Martínez, J.M. Rico

Changes in nutrient content of Palmaria palmata in response to variable light and upwelling in northern Spain

Journal of Phycology, 44 (1) (2008), pp. 50-59

Matanjun et al., 2009 P. Matanjun, S. Mohamed, N.M. Mustapha, K. Muhammad

Nutrient content of tropical edible seaweeds, Eucheuma cottonii, Caulerpa lentillifera and Sargassum polycystum

Journal of Applied Phycology, 21 (2009), pp. 75-80

da Saúde and (Portugal), INSA, 2006 Ministério da Saúde (Portugal)/INSA (2006). Tabela da composição de alimentos. 1st ed. INSA: Lisboa,

Mišurcová et al., 2014 L. Mišurcová, F. Buňka, J. Vávra Ambrožová, L. Machů, D. Samek, S. Kráčmar

Amino acid composition of algal products and its contribution to RDI 
Mišurcová et al., 2010 L. Mišurcová, S. Kráčmar, B. Klejdus, J. Vacek

Nitrogen content, dietary fiber, and digestibility in algal food products

Czech Journal of Food Science, 28 (2010), pp. 27-35

Nitschke and Stengel, 2015 U. Nitschke, D.B. Stengel

A new HPLC method for the detection of iodine applied to natural samples of edible seaweeds and commercial seaweed food products Food chemistry, 172 (2015), pp. 326-334

Paiva et al., 2014 L. Paiva, E. Lima, R.F. Patarra, A.I. Neto, J. Baptista

Edible Azorean macroalgae as source of rich nutrients with impact on human health

Food Chemistry, 164 (2014), pp. 128-135

Pangestuti and Kim, 2015 R. Pangestuti, S.-K. Kim

Chapter 6 - Seaweed proteins, peptides, and amino acids

B.T.D. Troy (Ed.), Seaweed Sustainability, Academic Press, San Diego (2015), pp. 125-140

Patarra et al., 2013 R.F. Patarra, J. Leite, R. Pereira, J. Baptista, A.I. Neto

Fatty acid composition of selected macrophytes

Natural Product Research: Formerly Natural Product Letters, 27 (2013), pp. 665-669

Patarra et al., 2011 R.F. Patarra, L. Paiva, A.I. Neto, E. Lima, J. Baptista

Nutritional value of selected macroalgae

Journal of Applied Phycology, 23 (2) (2011), pp. 205-208

Peinado et al., 2014 I. Peinado, J. Girón, G. Koutsidis, J.M. Ames

Chemical composition, antioxidant activity and sensory evaluation of five different species of brown edible seaweeds

Food Research International, 66 (2014), pp. 36-44

Pereira, 2012 Pereira, L. MACOI - Portuguese Seaweeds website, IMAR-CMA (University of Coimbra (2012). http://macoi.ci.uc.pt/ (accessed 2.12.16).

Rioux et al., 2017 L.-E. Rioux, L. Beaulieu, S.L. Turgeon

Seaweeds: A traditional ingredients for new gastronomic sensation

Food Hydrocolloids, 68 (2017), pp. 255-265

Rodrigues et al., 2015 D. Rodrigues, A.C. Freitas, L. Pereira, T.A.P. Rocha-Santos, M.W. Vasconcelos, M. Roriz, ..., A.C. Duarte

Chemical composition of red, brown and green macroalgae from Buarcos bay in Central West Coast of Portugal

Food Chemistry, 183 (2015), pp. 197-207

Romarís-Hortas et al., 2012 V. Romarís-Hortas, P. Bermejo-Barrera, A. Moreda-Piñeiro

Development of anion-exchange/reversed-phase high performance liquid chromatography-inductively coupled plasma-mass spectrometry methods for the speciation of bio-available iodine and bromine from edible seaweed

Journal of Chromatography A, 1236 (2012), pp. 164-176

Sánchez-Machado et al., 2003 D.I. Sánchez-Machado, J. López-Cervantes, J. López-Hernández, P. Paseiro-Losada, J. Simal-Lozano

High-Performance Liquid Chromatographic analysis of amino acids in edible seaweeds after derivatization with phenyl isothiocyanate Chromatographia, 58 (3) (2003), pp. 159-163

Silva et al., 2015 D.M. Silva, L.M.P. Valente, I. Sousa-Pinto, R. Pereira, M.A. Pires, F. Seixas, P. Rema

Evaluation of IMTA-produced seaweeds (Gracilaria, Porphyra, and Ulva) as dietary ingredients in Nile tilapia, Oreochromis niloticus L., juveniles. Effects on growth performance and gut histology

Journal of Applied Phycology, 27 (4) (2015), pp. 1671-1680 
WHO, FAO, UNU, 2007 WHO, FAO, UNU,

Protein and amino acid requirements in human nutrition. In Report of a Joint WHO/FAO/UNU Expert Consultation. WHO technical report series 935

WHO Press, Geneva (2007)

Yamaguchi and Ninomiya, 2000 S. Yamaguchi, K. Ninomiya

Umami and food patalability

The Journal of Nutrition, 130 (2000), pp. 921S-926S 